\title{
Comprehensive genotyping and clinical characterisation reveal 27 novel NKX2-1 mutations and expand the phenotypic spectrum
}

\author{
Anne Thorwarth, ${ }^{1,2}$ Sarah Schnittert-Hübener, ${ }^{1}$ Pamela Schrumpf, ${ }_{1}^{1}$ Ines Müller, ${ }^{2}$ \\ Sabine Jyrch, ${ }^{1}$ Christof Dame, ${ }^{3}$ Heike Biebermann, ${ }^{1}$ Gunnar Kleinau, ${ }^{1}$ Juri Katchanov, ${ }^{4}$ \\ Markus Schuelke, ${ }^{5}$ Grit Ebert, ${ }^{2}$ Anne Steininger, ${ }^{2}$ Carsten Bönnemann, ${ }^{6}$ \\ Knut Brockmann, ${ }^{7}$ Hans-Jürgen Christen, ${ }^{8}$ Patricia Crock ${ }_{1}^{9}$ Francis deZegher, ${ }_{1}^{10}$ \\ Matthias Griese, ${ }_{11}^{11}$ Jacqueline Hewitt, ${ }^{12}$ Sten Ivarsson, ${ }^{13}$ Christoph Hübner, ${ }^{5}$ \\ Klaus Kapelari, ${ }^{14}$ Barbara Plecko, ${ }^{15}$ Dietz Rating, ${ }_{1}^{16}$ Iva Stoeva, ${ }^{17}$ Hans-Hilger Ropers, ${ }^{2}$ \\ Annette Grüters, ${ }^{1}$ Reinhard Ullmann, ${ }^{2}$ Heiko Krude ${ }^{1}$
}

- Additional material is published online only. To view please visit the journal online (http://dx.doi.org/10.1136/ jmedgenet-2013-102248)

For numbered affiliations see end of article.

\section{Correspondence to} Professor Dr H Krude, Charité University Medicine Berlin, Institute for Experimental Pediatric Endocrinology, Augustenburger Platz 1, Berlin 13353, Germany; heiko.krude@charite.de Dr R Ullmann, Institut für Radiobiologie der Bundeswehr in Verbindung mit der Universität Ulm, D-80937

Munich, Germany;

ullmann@molgen.mpg.de

Received 23 December 2013 Revised 8 February 2014 Accepted 18 February 2014 Published Online First 8 April 2014

\section{CrossMark}

To cite: Thorwarth $A$ Schnittert-Hübener $S$, Schrumpf $\mathrm{P}$, et al. J Med Genet 2014;51:375-387.

\section{ABSTRACT}

Background NKX2-1 encodes a transcription factor with large impact on the development of brain, lung and thyroid. Germline mutations of NKX2-1 can lead to dysfunction and malformations of these organs. Starting from the largest coherent collection of patients with a suspected phenotype to date, we systematically evaluated frequency, quality and spectrum of phenotypic consequences of NKX2-1 mutations.

Methods After identifying mutations by Sanger sequencing and array CGH, we comprehensively reanalysed the phenotype of affected patients and their relatives. We employed electrophoretic mobility shift assay (EMSA) to detect alterations of NKX2-1 DNA binding. Gene expression was monitored by means of in situ hybridisation and compared with the expression level of MBIP, a candidate gene presumably involved in the disorders and closely located in close genomic proximity to NKX2-1.

Results Within 101 index patients, we detected 17 point mutations and 10 deletions. Neurological symptoms were the most consistent finding (100\%), followed by lung affection (78\%) and thyroidal dysfunction (75\%). Novel symptoms associated with NKX2-1 mutations comprise abnormal height, bouts of fever and cardiac septum defects. In contrast to previous reports, our data suggest that missense mutations in the homeodomain of NKX2-1 not necessarily modify its DNA binding capacity and that this specific type of mutations may be associated with mild pulmonary phenotypes such as asthma. Two deletions did not include NKX2-1, but MBIP, whose expression spatially and temporarily coincides with NKX2-1 in early murine development.

Conclusions The high incidence of NKX2-1 mutations strongly recommends the routine screen for mutations in patients with corresponding symptoms. However, this analysis should not be confined to the exonic sequence alone, but should take advantage of affordable NGS technology to expand the target to adjacent regulatory sequences and the NKX2-1 interactome in order to maximise the yield of this diagnostic effort.

\section{INTRODUCTION}

NKX2-1 (OMIM *600635), also known as TITF-1, TTF-1 or T/ebp, is a member of the homeodomaincontaining NK-2 gene family. ${ }^{1}$ It encodes a transcription factor, which is expressed during early development of thyroid, lung and forebrain regions, particularly the basal ganglia and hypothalamus. $^{2} 3$ In thyrocytes, NKX2-1 regulates the expression of thyroglobulin, thyreotropin receptor, thyroid peroxidase (TPO) and pendrin, and is therefore required for both development and maintenance of the thyroid gland. In the lung, NKX2-1 is implicated in the branching of the lobar bronchi, and at later stages of embryonic development, it regulates the expression of surfactant proteins in type II pneumocytes. In the brain, it has a central role in proper specification and migration of interneuron subtypes in the medial ganglionic eminence and telencephalon. ${ }^{4} 5$ However, little is known about the direct and indirect transcriptional targets of NKX2-1 in the central nervous system.

In mice, the disruption of the Nkx2-1 gene resulted in a severe, lethal phenotype in homozygous animals, characterised by pulmonary hypoplasia, absence of functional thyroid tissue and complex malformations of brain structures, including the basal ganglia, hypothalamus and pituitary. Heterozygous littermates remained unaffected. ${ }^{4}$ Against this background and in the light of the multifaceted role of NKX2-1 in normal lung, thyroid and brain development and function, a corresponding phenotype was also expected for germline mutations of NKX2-1 in humans. Indeed, patients with large chromosomal deletions of chromosome 14 encompassing NKX2-1 and several other genes showed malfunctioning of the thyroid, the lung and the central nervous system (CNS). ${ }^{67}$ Yet, it was not before the identification of the first intragenic point mutations that these symptoms could be unequivocally assigned to a dysfunction of NKX2-1. ${ }^{8-10}$ Notably, in contrast to mice, where only inactivation of both alleles resulted in a disease phenotype, all patients in these studies were heterozygous for the mutation, therefore suggesting a dominant mode of inheritance in humans. 
Considerable phenotypic variability in terms of organ involvement and expressivity was already evident in these first described patients and their affected relatives. All individuals suffered from a neurological disorder with profound muscular hypotonia and delay in motor development in their first months of life, followed by the onset of a movement disorder, mainly characterised by uncontrolled, jerky movements by means of a truncal chorea and peripheral athetosis. However, a functional defect of the thyroid was present in only half of the patients, variably manifesting as either severe congenital hypothyroidism $(\mathrm{CH})$ or merely elevated thyroid-stimulating hormone (TSH) levels. Even fewer patients presented with additional pulmonary affection ranging from severe neonatal distress to the occurrence of frequent and severe pneumonias in the first two to three years of life. ${ }^{8-10}$

Since then, 20 case reports and 7 series of patients with a total of 161 patients and 77 mutations have been reported (see online supplementary table 1), ${ }^{6-33}$ but altogether they have failed to reveal a correlation between type, size and position of mutations and a specific phenotype. The only exceptions were reports on oligodontia in individuals harbouring chromosomal deletions simultaneously encompassing NKX2-1 and PAX9, reflecting the role of PAX9 in odontogenesis. ${ }^{34-36}$ This overall lack of genotype-phenotype correlation was surprising given the fact that the two activating domains of NKX2-1 are supposed to be differentially involved in thyroid and pituitary development, implying that at least different missense mutations might cause different phenotypes. ${ }^{37}$

One reason for this unexpected finding could be a biased composition of patient cohorts in all studies published to date. This bias may be attributed to differences in the main emphasis of these studies, either on Benign hereditary chorea (BHC), ${ }^{15} 22{ }^{38} \mathrm{CH}^{13}{ }^{14}$ or chromosomal aberrations, ${ }^{16} 39$ respectively, or may have originated from particularities in disease naming, ${ }^{17}$ which could have led to exclusion of patients that do not display the full spectrum of possible symptoms. Therefore, a comprehensive description of mutation frequency and quality within a larger cohort of non-biased patients is still missing. We have taken advantage of our 10-year experience in diagnosing NKX2-1 deficiency ${ }^{8}$ to collect a cohort of 101 patients with BHC or the combination of thyroid, lung or neurological symptoms. Here we report the results of the most comprehensive screen for point mutations and DNA copy number variants (CNVs) affecting NKX2-1 in patients with an indicative phenotype to date. Starting from the subset of index patients with confirmed NKX2-1 mutations as well as their mutation-positive relatives, we have re-evaluated the spectrum of symptoms associated with this genotype. Moreover, we provide evidence for DNA copy number changes in next proximity to NKX2-1 that do result in a phenotype comparable to that of intragenic mutations.

\section{MATERIALS AND METHODS}

\section{Patients and DNA isolation}

Over a period of 10 years, samples of 101 patients (57 male, 44 female, age 0-18 years) were referred for diagnosis characterised by clinical symptoms as follows: (i) triad of thyroid dysfunction, neurological deficit and pulmonary disease in 26 patients (25.5\%); (ii) thyroid dysfunction and neurological deficit in 48 patients (47.1\%); (iii) isolated neurological deficit in 16 patients (15.7\%); (iv) neurological deficit and pulmonary malfunction in 8 patients $(7.8 \%)$ and $(\mathrm{v})$ thyroid dysfunction and pulmonary disease in 4 patients (3.9\%). All patients have been classified by experienced clinicians from 35 medical centres in 18 countries.
Genomic DNA of all subjects as well as of healthy controls was isolated from peripheral blood leucocytes using the Qiagen DNA blood mini kit (Qiagen, Hilden, Germany). Informed consent for the genetic diagnosis was obtained from the parents according to the local regulations (ethical approval no. EA2-089-06).

\section{DNA sequencing analysis}

The entire coding region of NKX2-1 was amplified in two fragments from genomic DNA (forward primer: 5'-CGTCCC CAGACTCGCTCGCTC-3'/5'-CCTCCTCTTCCTTCC TCC-3'; reverse primer: 5'-CTCAGGAGGTGCGGCGAGAG CCGTC-3'/ 5'-GAGGGAAGCGGTGAGGCAGAG-3'). Exons 1-3 were sequenced using V3 kit and ABI 3130xl Genetic Analyzer (Applied Biosystems, Foster City, CA) applying appropriate primers. DNA of patients 16 and 24 were additionally cloned into a TOPO cloning vector (Invitrogen, Groningen, The Netherlands) as described previously to delineate allele distribution. If DNA was available, the inheritance of identified sequence variants was analysed in family members.

\section{NKX2-1 structural homology model}

For model design of the human NKX2-1, the already published NMR structure of the homologous rat thyroid transcription factor homeodomain (Protein-Database entry code $1 \mathrm{FTT}^{40}$ ) served as a structural template. The interacting DNA fragment was arranged according to a nearly identical and superimposed X-ray structure of the NKX2-5 homeodomain (gray backbone) bound with DNA (PDB entry code 3RKQ). The homeobox is constituted by three helices, which are connected by loops (figure 1C). For model preparation, Sybyl 8.1 was used (Tripos Inc., St. Louis, Missouri, 63144, USA) and the image was produced with the PyMOL software (The PyMOL Molecular Graphics System, V.1.3 Schrödinger, LLC).

\section{Electrophoretic mobility shift assay (EMSA)}

Wild-type and mutant NKX2-1 proteins were in vitro translated from the pCMX expression vector using the TNT reticulocyte system (Promega, Southampton, UK). Synthetic oligonucleotide probes corresponding to the $3^{\prime}$ NKX2-1 binding site on the thyroglobulin promoter were labelled with $\left[{ }^{32} \mathrm{P}\right] \mathrm{dCTP}$ by Kleenow polymerase and EMSA were performed as described previously. ${ }^{41} 425 \mu \mathrm{g}$ of in vitro translated human wild-type NKX2-1 or mutant proteins (NKX2-1 p.Ser169X, NKX2-1 p. Gln182X, NKX2-1 p.Val205Phe, NKX2-1 p.Lys265LysfsX87, NKX2-1 p.Thr203Arg) were incubated with $1 \mu \mathrm{g}$ BSA in the binding buffer $(10 \mathrm{mmol} / \mathrm{L}$ TrisHCl $\mathrm{pH} 7.5,1 \mathrm{mmol} / \mathrm{L}$ EDTA, $4 \%$ Ficoll $1 \mathrm{mmol} / \mathrm{L}$ dithiothreital and $2 \mathrm{mmol} / \mathrm{L}$ PMSF). After incubation for $20 \mathrm{~min}$ at $30^{\circ} \mathrm{C}, 100 \mathrm{fmol}$ of the end-radiolabeled oligonucleotide was added to the reaction and incubated for additional $45 \mathrm{~min}$ at $30^{\circ} \mathrm{C}$. The oligonucleotide $5^{\prime}$-CACTGC CCAGTCAAGTGTTCTTGA-3' contains the rat NKX2-1 binding site, which is located at nucleotides -72 to -66 relative to the transcription start site of the thyroglobin gene (NCBI accession no. X06162). ${ }^{43-45}$ Electrophoresis was performed in a $5 \%$ native polyacrylamide gel in $0.5 \times \mathrm{x}$ TBE buffer $\mathrm{pH} 8.3$ with $34 \mathrm{~mA}$ at $4^{\circ} \mathrm{C}$ for approximately $2.5 \mathrm{~h}$. Protein complexes were visualised by autoradiography.

\section{Mini gene reporter assay and cell transfection}

The entire genomic region of NKX2-1 (Isoform 2 NM_003317.3) of a wild-type control DNA and two patients' (26 and 27) DNA was cloned into the eukaryotic expression vector pCS2+. CHO-K1 cells $\left(10^{6} / 10 \mathrm{~cm}\right.$ dish) were transfected with $5 \mu \mathrm{g}$ plasmid DNA using metafectene (Biontex, Munich, Germany) 

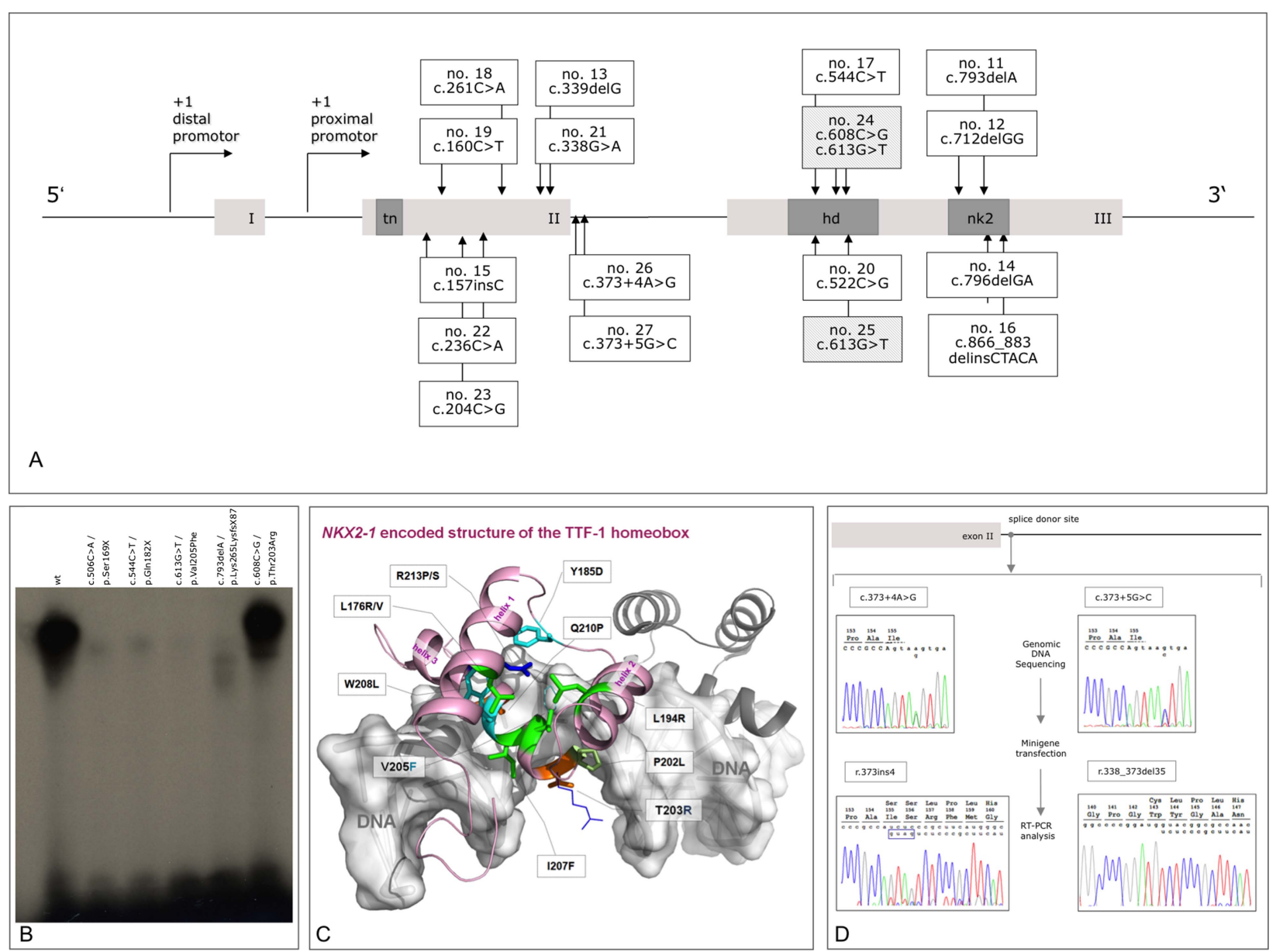

Figure 1 Position and functional consequences of NKX2-1 mutations. (A) Distribution of 17 novel point mutations with respect to the functional domains of NKX2-1 isoform 2 (REFSEQ NM_003317.3). Distal and proximal promoters ${ }^{86}$ are indicated by arrows; functional domains are shown in dark grey (tn, tin domain; hd, homeodomain; nk2, NK2 domain). (B) DNA binding characteristics of mutant NKX2-1. Electromobility shift assay testing wild-type and mutant NKX2-1 binding to a labelled probe corresponding to the NKX2-1 binding site of the TPO promoter. wt (lane 1); c.506C >A/p.Ser169X ( ${ }^{8}$ lane 2); c.544C>T/p.Gln182X (no. 17, lane 3); c.613G>T/p.Val205Phe (nos. 24/1 and 25, lane 4); c.793delA/p. Lys265LysfsX87 (no. 11, lane 5); c.608C>G/p.Thr203Arg (no. 24/2, lane 6); see text for details. (C) Structural homology model. Visualisation of the putative mode of binding between a human NKX2-1 homeobox (light-magenta backbone) and a fragment of DNA (white, translucent surface). The wild-type positions of known naturally occurring mutations are shown as sticks (colour code: green, hydrophobic side chain properties; cyan, aromatic; orange, hydrophilic; blue, positively charged; light green, proline). The side chains and potential orientations of two mutations described in this study —at positions 203 (p. T203R) and 205 (p. V205F) —are additionally visualised as lines. (D) Splicing defects caused by intronic point mutations. Mutant nos. 26 and 27 were analysed by mini gene reporter assays. Sequencing chromatograms of genomic DNA (c.373+4A>G/c.373 $+5 \mathrm{G}>\mathrm{C}$ variants) and RNA after CHO cell transfection and reverse transcription (r.373ins4/ r.338_373del35) are depicted in the upper and lower two boxes, respectively.

according to the manufacturer's protocol. Three days after transfection, cells were harvested, total RNA was extracted using TRIzol (Sigma, Deisenhausen, Germany) and mRNA was isolated with the oligo-Tex mRNA kit (Qiagen, Hilden, Germany). Reverse transcription was performed using oligo-dT primer and M-MLV Reverse Transcriptase (Promega, Mannheim, Germany). Subsequent PCR was performed, and PCR products were directly sequenced.

\section{Customised array CGH analysis}

Sixty individuals negative for NKX2-1 point mutations were selected for DNA copy number analysis by means of highresolution array $\mathrm{CGH}$ employing a custom $44 \mathrm{k}$ oligonucleotide array (Agilent, Santa Clara, California, USA) representing genomic region chr14: 32055352-41215621 (HG18). As the 5' breakpoint was excluded in the identified deletion in case 5, results were verified by array $\mathrm{CGH}$ on a $244 \mathrm{k}$ oligonucleotide array from Agilent following the manufacturer's instructions (protocol no. G4410-90010). Labelling and hybridisation were performed according to the manufacturer's recommendations (protocol no. G4410-90010). Arrays were scanned with the G2565BA Agilent Microarray Scanner System (resolution $5 \mu \mathrm{m}$; PMT 100\% for Cy3/Cy5, respectively) (Agilent Inc. Santa Clara, California, USA). Image processing was performed using Feature Extraction Software v9.1, and data were further analysed in CGH Analytics Software V.3.4.27 (Agilent) using the default settings. All genomic coordinates given in this paper refer to NCBI Build 36 (HG18). Confirmatory experiments were performed with breakpoint spanning PCR and direct sequencing of amplicons. The sequence variant was analysed in family members if DNA specimens were available.

\section{In situ hybridisation}

For in situ hybridisation, E11.5 NMRI wild-type embryos were used. Mice were mated, and noon of the day of the vaginal plug 
was considered E0.5. Embryos were dissected in ice-cold $1 \times$ PBS, fixed in 4\% PFA, dehydrated and embedded in paraffin. $6 \mu \mathrm{m}$ tissue sections were prepared on a microtome, mounted on silanized slides and dried at $37^{\circ} \mathrm{C}$. For hybridisation, probes were labelled with digoxigenin (DIG). The Nkx2-1 probe contained nucleotides c.494-992 (NM_009385.2), the Mbip probe c.574-145 (NM_145442.2), matching the probe used in Ref. ${ }^{46}$ Probes were amplified from cDNA by PCR, cloned into the pCRII-vector (Invitrogen, Carlsbad, USA), linearised and transcribed with T7 or Sp6 polymerase. The in situ hybridisation protocol was kindly provided by the Research Group Mundlos (Max Planck Institute for Molecular Genetics, Berlin, Germany) and has been adapted from Ref. ${ }^{47}$. Briefly, tissue sections were dewaxed, rehydrated, digested with Proteinase $\mathrm{K}$ and acetylated. Hybridisation with DIG-labelled probes was carried out at $68^{\circ}$ C. Following posthybridisation washes, sections were incubated with an AP-conjugated a-DIG-antibody (Roche Applied Science, Mannheim, Germany) and signal was detected with NBT/BCIP (Roche Applied Science, Mannheim, Germany).

\section{Detailed phenotyping}

For detailed phenotyping of mutation-positive individuals, a total of 28 patients (17 male, 11 female, age 1.5-44 years/ 18 index patients, 8 relatives) was reanalysed (ethical approval no. EA2-089-06). A questionnaire containing 187 items was used for obtaining clinical data and information on patient history. Video documentation of the patient's movement disorder was carried out according to standardised protocols, followed by independent classification by two experienced neurologists (using the Burke-Fahn-Marsden Dystonia Rating Scale).

For graphical representation of phenotype data, a heatmap was generated using ' $\mathrm{R}^{48}$ (http://www.R-project.org/) and 'ggplot2' (http://ggplot2.org/).

\section{RESULTS}

\section{NKX2-1 intragenic mutations}

Sequencing of 101 patients with a phenotype suggestive for a dysfunction of NKX2-1 revealed 17 intragenic mutations in 17 patients, of which 15 are novel, whereas the remaining two have already been described in unrelated individuals. ${ }^{8}$ All mutations with respect to their location in the protein are depicted in figure 1A. As listed in more detail in table 1, we have identified six frameshift mutations due to insertion/deletion mutations (indels), one insertion and one deletion-insertion resulting in premature stop codons or elongated protein sequences, seven nonsense and one missense mutation. Furthermore, one compound-heterozygous missense mutation was identified, of which one allelic variant [c.703G $>$ T] occurred de novo, whereas the other [c.698C > G] could also be identified in two siblings and the mother. We carried out EMSA to elucidate the effect of the two missense mutations on NKX2-1 DNA binding capacity in comparison to two nonsense-elongation and one frameshift-elongation mutations. These experiments verified loss of DNA binding capacity for the three nonsense and frameshift mutations as well as for variant Val235Phe, whereas p. Thr233Arg appeared to have a DNA binding capacity equivalent to the wild-type protein (figure $1 \mathrm{~B}$ ). So far, all missense mutations within the homeobox domain were shown to interfere with DNA binding. We developed a homology structure model to delineate the binding capacity of p.Thr233Arg in more detail. The homeobox is constituted of three helices, which are connected by loops. The model demonstrates that the helix 3 is most important for DNA binding, whereby the exact adjustment between the helices 1 and 3 relative to each other is of general significance for NKX2-1 functions. In consequence, mutations at any amino acid in these helices either interfere with the correct fold of the box (intramolecular interactions) or they modulate intermolecular interactions. The wild-type positions of previously described mutations were introduced in the model as well as the side chains and potential orientations of two mutations described in this study-at positions 203 (p.Thr203Arg) and 205 (p.Val205Phe) (figure 1C).

In addition, we performed mini gene reporter assays for the two intronic mutations that potentially affect splice site mutations (nos. 26 and 27). Both mutations result in splice variants that are each truncating the functional domains in exon 3 by a frame shift (figure 1D).

\section{NKX2-1 CNV}

DNA of 60 patients negative for NKX2-1 point mutations was further investigated for the presence of copy number changes in the NKX2-1 genomic region by high-resolution array CGH. By using a 44k customised oligonucleotide array, we identified 10 heterozygous deletions affecting the chromosomal region $14 \mathrm{q} 13$ in 10 patients. All $10 \mathrm{CNVs}$ are differing in size and were verified by breakpoint spanning PCR and sequencing (table 1 , figure $2 \mathrm{~B}$ and online supplementary figure S2). The largest deletion is spanning 15.17 $\mathrm{Mb}$ (no. 6, chr14: 31766412-46945775) and comprises 45 RefSeq genes, including NKX2-1. The NKX2-1 gene comprises two exon and one intron covering $3306 \mathrm{bp}$. Incomplete loss of NKX2-1 has exclusively been observed in no. 4 , where the deletion was limited to exon 1 and the distal NKX2-1 promoter. Figure 2A displays the extent of all $\mathrm{CNVs}$ in their genomic context, according to the UCSC Genome Browser (HG18).

\section{CNV affecting MBIP}

Two CNVs, among them the smallest aberration encompassing $76.67 \mathrm{~kb}$ (no. 10, chr14: 35802212-35878882), did not include NKX2-1, but led to a heterozygous loss of the $5^{\prime}$-neighbouring gene $M B I P$, which encodes for the MAP3K12 binding inhibitory protein (figure $3 \mathrm{~A}$, table 1). Deletion no. 9 occurred de novo in a patient with chorea and mild hypothyroidism (3B.1) while deletion no. 10, which exclusively affects MBIP, was transmitted in a large kindred with chorea of dominant inheritance (figure 3B.2). We performed Mbip in situ hybridisation of early mice embryos and detected an identical pattern of expression in comparison to NKX2-1, including the basal ganglia, forebrain, thyroid and lung (figure $3 \mathrm{C}$ ). We sequenced the coding region of $M B I P$ in 74 patients negative for NKX2-1 mutation, but did not detect any alteration (data not shown).

\section{Phenotype spectrum in index patients}

Altogether, we have identified 25 new cases of NKX2-1 mutations and two additional patients with small deletions close to NKX2-1 affecting the adjacent MBIP gene. Among them, 11 patients displayed the complete triad of movement, thyroid and lung symptoms, 13 patients the dual combination of movement defects and thyroid dysfunction, and 3 patients showed isolated movement disorder (figure 4A). Phenotype of cases with NKX2-1 mutation did not differ from the two cases of MBIP mutations, as the latter were both affected by chorea associated with mild thyroid dysfunction in one of them. In all patients, neurological impairment was present, characterised by benign choreoathetosis preceded by muscular hypotonia in early infancy. Within the group of mutation-negative cases (figure 4B), 15 patients were affected by the triad of movement, thyroid and pulmonary symptoms, putatively caused either by variants in the 
Table 1 Overview of identified NKX2-1 deletions and intragenic mutations

\begin{tabular}{|c|c|c|c|c|c|c|c|c|c|c|}
\hline \multirow[b]{2}{*}{ No. } & \multirow[b]{2}{*}{ DNA sequence } & \multirow[b]{2}{*}{ Size } & \multirow[b]{2}{*}{$\begin{array}{l}\text { Protein } \\
\text { localisation }\end{array}$} & \multirow[b]{2}{*}{ Protein level } & \multicolumn{2}{|c|}{ Inheritance } & \multicolumn{4}{|l|}{ Phenotype } \\
\hline & & & & & & $\begin{array}{l}\text { Affected } \\
\text { family } \\
\text { members* }\end{array}$ & $\begin{array}{l}\text { Thyroid } \\
\text { dysfunction }\end{array}$ & $\begin{array}{l}\text { Choreoathetosis/ } \\
\text { muscular hypotonia }\end{array}$ & $\begin{array}{l}\text { Pulmonary } \\
\text { malfunction }\end{array}$ & Sex \\
\hline 1 & $\begin{array}{l}\text { chr14:g } \\
\text { (36042742_36142540)del }\end{array}$ & 99798 bp & Entire protein & p.0 & $A D$ & M 2 & Yes & Yes & Yes & $M$ \\
\hline 2 & $\begin{array}{l}\text { chr14:g } \\
\text { (35138127_37502915)del }\end{array}$ & $\begin{array}{l}2364788 \\
\text { bp }\end{array}$ & Entire protein & p.0 & $A D$ & M 1 & Yes & Yes & No & $M$ \\
\hline 3 & $\begin{array}{l}\text { chr14:g } \\
\text { (35221080_36553158)del }\end{array}$ & $\begin{array}{l}1332078 \\
b p\end{array}$ & Entire protein & p.0 & $\mathrm{n} / \mathrm{a}$ & $\mathrm{n} / \mathrm{a}$ & No & Yes & No & $\mathrm{F}$ \\
\hline 4 & $\begin{array}{l}\text { chr14:g } \\
\text { (36058432_36825446)del }\end{array}$ & 767014 bp & Entire protein & p.0 & $\mathrm{n} / \mathrm{a}$ & n/a & Yes & Yes & No & $M$ \\
\hline 5 & $\begin{array}{l}\text { chr14:g } \\
\text { (34071433_36246414)del }\end{array}$ & $\begin{array}{l}2174981 \\
\text { bp }\end{array}$ & Entire protein & p.0 & $\mathrm{n} / \mathrm{a}$ & $\mathrm{n} / \mathrm{a}$ & Yes & Yes & No & $\mathrm{F}$ \\
\hline 6 & $\begin{array}{l}\text { chr14:g } \\
\text { (31766511_46944545)del }\end{array}$ & $\begin{array}{l}15178034 \\
\text { bp }\end{array}$ & Entire protein & p.0 & $\mathrm{n} / \mathrm{a}$ & $\mathrm{n} / \mathrm{a}$ & Yes & Yes & No & $M$ \\
\hline 7 & $\begin{array}{l}\text { chr14:g } \\
\text { (35883857_38226260)del }\end{array}$ & $\begin{array}{l}2342403 \\
\text { bp }\end{array}$ & Entire protein & p.0 & $A D$ & F 2 & Yes & Yes & Yes & $M$ \\
\hline 8 & $\begin{array}{l}\text { chr14:g } \\
\text { (35989750_36754641)del }\end{array}$ & 764891 bp & Entire protein & p.0 & De novo & Nil & Yes & Yes & Yes & $\mathrm{F}$ \\
\hline 9 & $\begin{array}{l}\text { chr14:g } \\
\left(35257445 \_35257464+\right. \\
\text { 35257487_35984627)del }\end{array}$ & 727181 bp & $\begin{array}{l}\text { Del excluding } \\
\text { NKX2-1 }\end{array}$ & p.? & De novo & Nil & Yes & Yes & No & $\mathrm{F}$ \\
\hline 10 & $\begin{array}{l}\text { chr14:g } \\
\text { (35801941_35878529)del }\end{array}$ & 76588 bp & $\begin{array}{l}\text { Del excluding } \\
\text { NKX2-1 }\end{array}$ & p.? & $A D$ & $\mathrm{M} 2 / \mathrm{F} 2$ & No & Yes & No & $M$ \\
\hline 11 & c.793delA & & NK2 & p.Lys265LysfsX87 & De novo & Nil & Yes & Yes & No & $M$ \\
\hline 12 & c.712delGG & & NK2 & p.Gly238ArgfsX170 & $A D$ & $\mathrm{~F} 2$ & Yes & Yes & Yes & $M$ \\
\hline 13 & c.339delG & & TN-HD & p.Trp113CysfsX16 & De novo & Nil & No & Yes & No & $M$ \\
\hline 14 & c.796delGA & & NK2 & p.Asp266Argfs142X & De novo & Nil & Yes & Yes & No & $\mathrm{F}$ \\
\hline 15 & c.157insC & & TN-HD & p.Met53HisfsX355 & De novo & Nil & Yes & Yes & Yes & $\mathrm{F}$ \\
\hline 16 & c.866_883delinsCTACA & & NK2-X & p.GIn289ProfsX59 & De novo & Nil & Yes & Yes & Yes & $M$ \\
\hline 17 & c. $544 C>T$ & & $H D$ & p.GIn182X & De novo & Nil & Yes & Yes & Yes & $\mathrm{F}$ \\
\hline 18 & c. $261 C>A$ & & TN-HD & p.Cys87X & $A D$ & $\mathrm{~F} 2$ & Yes & Yes & Yes & $M$ \\
\hline 19 & c. $160 \mathrm{C}>\mathrm{T}$ & & TN-HD & p.Gln55X & $\begin{array}{l}\text { Father } n / \\
\text { a; mother } \\
\text { WT }\end{array}$ & $\mathrm{n} / \mathrm{a}$ & Yes & Yes & No & $\mathrm{F}$ \\
\hline 20 & c. $522 C>G$ & & HD & p.Tyr174X & n/a & n/a & Yes & Yes & Yes & $M$ \\
\hline 21 & c. $338 \mathrm{G}>\mathrm{A}$ & & TN-HD & p.Trp113X & $\mathrm{n} / \mathrm{a}$ & $\mathrm{n} / \mathrm{a}$ & Yes & Yes & No & $M$ \\
\hline 22 & c. $236 \mathrm{C}>\mathrm{A}$ & & TN-HD & p.Ser79X & $A D$ & $\mathrm{~F} 2$ & Yes & Yes & No & $\mathrm{F}$ \\
\hline 23 & c. $204 C>G$ & & TN-HD & p.Tyr68X & $A D$ & F 1 & Yes & Yes & Yes & $M$ \\
\hline 24 & {$[\mathrm{c} .608 \mathrm{C}>\mathrm{G}]+[\mathrm{c} .613 \mathrm{G}>\mathrm{T}]$} & & $H D$ & $\begin{array}{l}\text { [p.Thr203Arg]+[p. } \\
\text { Val205Phe] }\end{array}$ & $\begin{array}{l}\text { AD/de } \\
\text { novo }\end{array}$ & F 3 & Yes & Yes & No & $M$ \\
\hline 25 & c. $613 \mathrm{G}>\mathrm{T}$ & & $H D$ & p.Val205Phe & De novo & Nil & Yes & Yes & No & $\mathrm{F}$ \\
\hline 26 & c. $373+4 \mathrm{~A}>\mathrm{G} /$ r.373ins4 & & $\begin{array}{l}\text { TN-HD (splice } \\
\text { donor site) }\end{array}$ & p.lle155SerfsX126 & De novo & Nil & Yes & Yes & Yes & $M$ \\
\hline 27 & $\begin{array}{l}\text { c. } 373+5 G>C \text { I } \\
\text { r.338_373del35 }\end{array}$ & & $\begin{array}{l}\text { TN-HD (splice } \\
\text { donor site) }\end{array}$ & p.Trp143CysfsX138 & $\mathrm{n} / \mathrm{a}$ & $\mathrm{n} / \mathrm{a}$ & Yes & Yes & No & $M$ \\
\hline 28 & $\begin{array}{l}\text { chr14:g } \\
\text { (32446471_41666818)del }\end{array}$ & $9.2 M b p$ & Entire protein & p.0 & De novo & Nil & Yes & Yes & Yes & $M$ \\
\hline 29 & c.585nsGG & & $H D$ & p.Leu195GlyfsX3 & De novo & Nil & Yes & Yes & Yes & $M$ \\
\hline 30 & c. $506 C>A$ & & $H D$ & p.Ser169X & $n / a$ & $n / a$ & Yes & Yes & No & $M$ \\
\hline 31 & c. $261 C>A$ & & $T N-H D$ & p.Cys87X & $A D$ & $F 1$ & Yes & Yes & Yes & $M$ \\
\hline 32 & c. $613 G>T$ & & $H D$ & p.Val205Phe & De novo & Nil & Yes & Yes & Yes & $M$ \\
\hline
\end{tabular}

NKX2-1 enhancer and/or promoter region or by mutations in another yet unknown candidate gene.

Overall, the phenotypic spectrum of all 32 index mutationpositive patients that we identified in this report as well in our initial publication from 2002 (see online supplementary figure S3A) is dominated by the occurrence of a movement disorder in all patients.
However, accompanying thyroid dysfunction was the most consistent combination of symptoms, followed by the triad of thyroid, lung and movement affection, whereas only three patients showed an isolated movement disorder. Moreover, comparison of the index cases who were initially examined for their presumably more severe phenotype with other affected family members who represent 


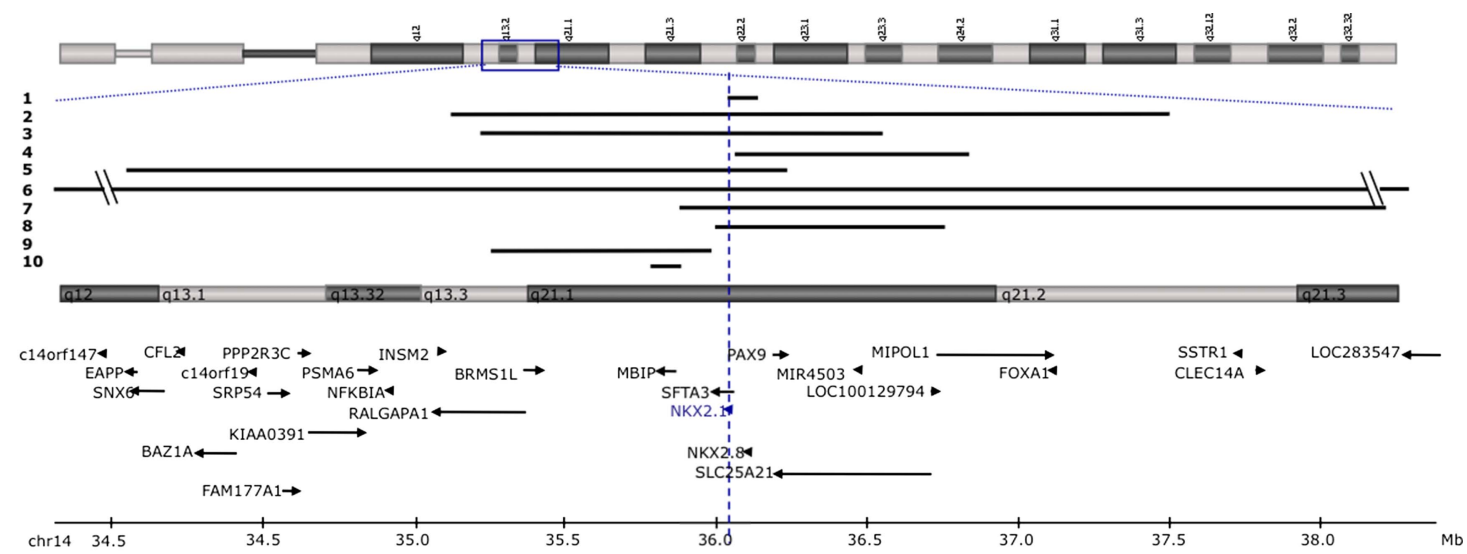

A
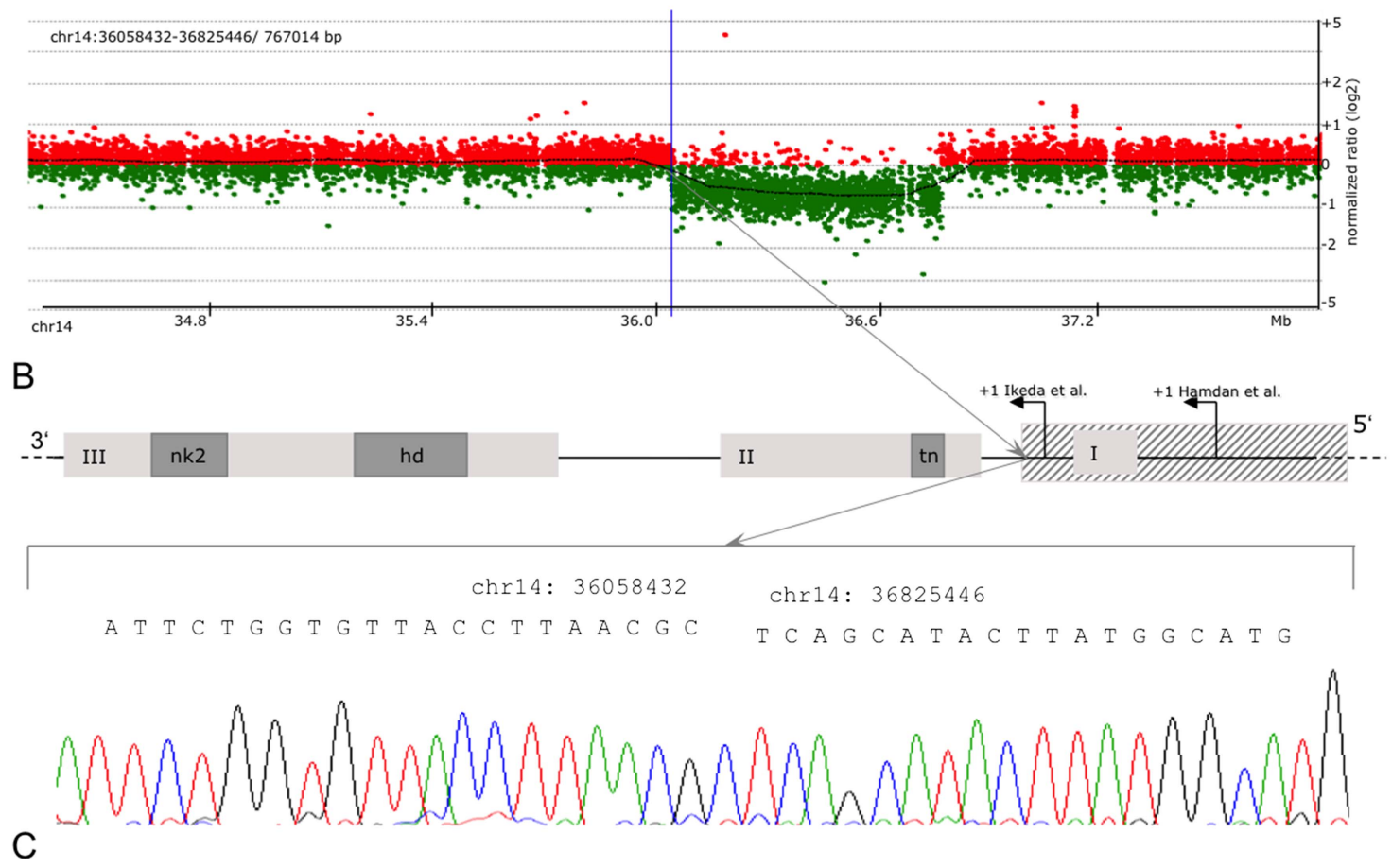

Figure 2 Disease-associated copy number variants (CNVs). (A) Localisation of all CNVs reported in this study. The vertical line highlights the position of NKX2-1 on chromosome 14q13.3. (B) Array CGH profile of deletion no. 4 encompassing chr14: 35989750-36754641 (array CGH results of all other cases are summarised in online supplementary figure 2). (C) CNV verification by breakpoint spanning PCR and amplicon sequencing on the example of the proximal border of deletion no. 4 (hatched box).

thereby an unbiased cohort of mutation-positive patients revealed an identical spectrum of symptom association (see online supplementary figure S3).

\section{Extended phenotyping}

In order to define a more detailed phenotype of NKX2-1 deficiency in a larger cohort of patients, we performed a clinical study in 28 mutation-positive patients ( 7 deletions/21 point mutations) by recollecting all available clinical and history data as well as video documentation of individual movement statuses (figure 5A,B).

To date, a wide range of neurological descriptions has been used for the movement disorders in the available reports on NKX2-1 deficiency, which is namely 'choreoathetosis' in the majority of cases. We aimed to gain an objective neurological classification through independent judgement. In 17 of 22 videos, movement disorder was classified as chorea, athetosis was stated in 9, ataxia in 7 and dystonia in 6 . As either chorea or athetosis was present in all examined patients, our data are suggesting that choreoathetosis is in fact the most frequent form of movement disorder in NKX2-1 deficiency.

In addition to the gross motor disorder, 23 patients were affected by dysarthria, while speech comprehension was normal in all. An attentiveness disorder was mentioned in 22 patients. Mental development was quantified by IQ testing in 12 patients, showing low normal levels in most cases (exact values were available in three individuals with 80,116 and 119 IQ points, respectively (K-ABC test and CPM-test)). EEG recording was available in 16 patients, with 3 to have suspicion of focal lesions, while no seizures were reported in any of them. MRI of the CNS was available in nine patients, with no major pathological findings (Rathkes pouches $n=2$ and hypoplastic pallidum $n=1$ ).

In 23 patients, thyroid defects were present as $\mathrm{CH}(\mathrm{n}=11)$, hyperthyreotropinemia $(n=12)$ and thyroid dysgenesis $(n=14$, 

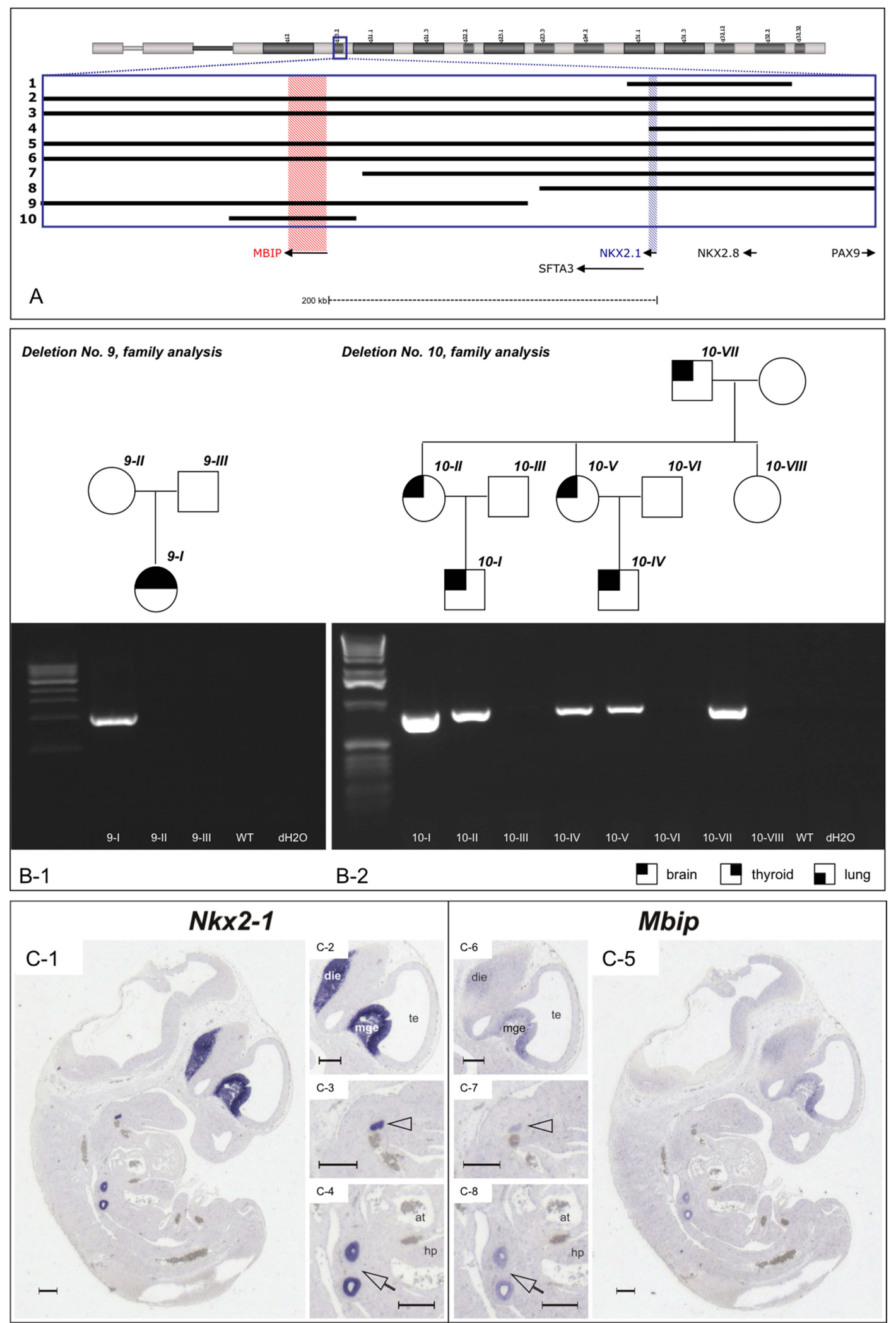

Figure 3 Copy number variants (CNVs) not including NKX2-1. (A) Close-up of chr14: 35,739,446-36,221,024 (Hg18). The positions of NKX2-1 and MBIP are highlighted in blue and red, respectively. Note that CNVs nos. 9 and 10 do not affect NKX2-1. (B) Breakpoint spanning PCR verifying the deletion in index patients nos. 9 and 10 and their relatives; see legend at the bottom for phenotype symbols. All genomic coordinates are given for Hg18. (C) Nkx2-1 and Mbip co-expression in mouse embryonic tissues. Nkx2-1 and Mbip in situ hybridisations on adjoining sagittal sections of an E11.5 wild-type embryo. Nkx2-1 and Mbip have common expression domains in the diencephalon, the median ganglionic eminence, the lung anlage and the thyroid primordium. C1-C4, Nkx2.1; C5-C8, Mbip in situ hybridisation. Panels C2-C4 and C6-C8 represent enlargements of C1 and C5, respectively. Arrowheads, thyroid primordium; arrows, lung anlage; die, diencephalon; mge, median ganglionic eminence; te, telencephalic vesicle; at, atrium; hp, hepatic primordium. Scale bars represent $250 \mu \mathrm{m}$. 


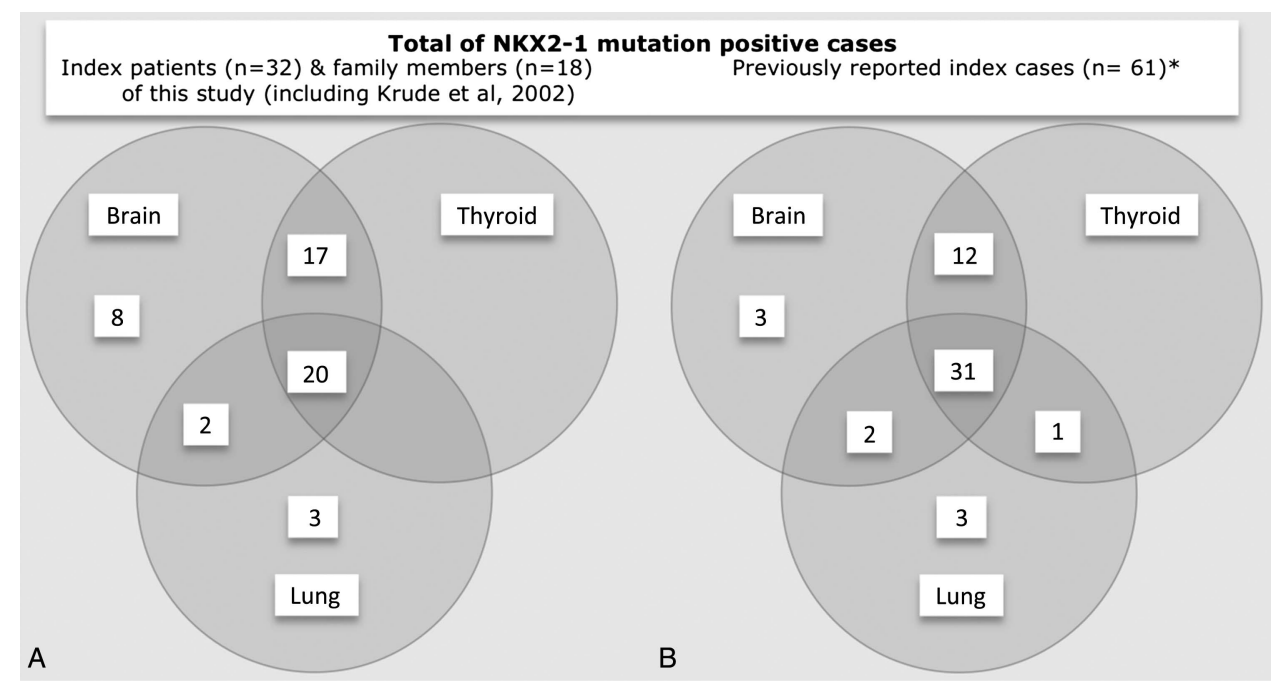

Figure 4 Brain, thyroid and lung involvement in patients with and without NKX2-1 mutations. Venn diagrams demonstrating that the triad of symptoms is enriched in mutation-positive patients. (A) Symptoms in patients with NKX2-1 deficiency (27/101). (B) Symptoms in patients without NKX2-1 deficiency (74/101). Two further Venn diagrams, one focusing on the phenotype of 18 family members and another one including also the 5 index patients of our previous study, ${ }^{8}$ are given in online supplementary figure S3. Two further Venn diagrams demonstrating that symptom involvement is identical in index cases ( $n=32$, including also the five index patients of our previous study ${ }^{8}$ to that of family members ( $n=18$ ), except three patients with isolated asthma phenotype) are given in online supplementary figure S3.

among them athyreosis $n=2$, hemithyroid $n=2$, thyroid hypoplasia $\mathrm{n}=10$ ).

Careful case history revealed a high incidence of lung affection, that is, in 22 of the 28 patients. In 13 patients, a respiratory distress syndrome with need for oxygen treatment during the neonatal period was reported. Fifteen patients were affected by recurrent pneumonias requiring antibiotic treatment (incidence ranging from 3 per annum to 12 per annum) in the first 6 years of life. In one patient, the pneumonic episodes persisted beyond that age, prior to diagnosis of a lung sequester. Spontaneous pneumothoraces (four relapses) occurred in another patient.

According to the murine phenotype in knockout animals with severe hypothalamic defects, we extended our exploration to various other symptoms, herein focusing on hypothalamic function. In 19 patients, bouts of fever episodes without evidence for infectious causes were recorded; 11 patients had increased appetite with reduced satiety, although BMI values were normal in all patients; in 14 patients, thirst was abnormally diminished, and in 10 patients a disturbed rhythm of sleep was reported.

Notably, patients' height standard deviation score (SDS) values revealed a trend for lower body length (median value $-0.84 \mathrm{SDS}$, see figure $5 \mathrm{~A}$ ), and two patients even received growth hormone therapy (SDS values -3.89 and -2.08 , respectively).

In seven individuals, a congenital heart defect (ventricular or atrial septum defect, respectively) was present, of which none needed surgical intervention and three patients were seen with oligodontia. Furthermore, six pregnancies had breech presentation at birth, hypothetically giving evidence for intrauterine hypokinesia due to muscular hypotonia

\section{DISCUSSION}

Despite the key role of NKX2-1 in thyroid development, ${ }^{49}$ several comprehensive screening approaches failed to detect NKX2-1 mutations in patients with $\mathrm{CH}^{50-52}$ Only when the presumptive NKX2-1 deficiency phenotype had been extended so that it also took into account the impact of NKX2-1 on development and function of other organs such as lung and brain, the first mutations were identified. ${ }^{8} 9$

\section{Core phenotype associated with NKX2-1 deficiency}

Neurological impairment, mainly in the form of choreoathetosis, was present in all index patients identified in this study. This is in accordance with all reports in literature so far, apart from those neonatal cases with severe lung affection, who died before the onset of neurological symptoms. ${ }^{20} 28$ The triad of symptoms (including defects of thyroid and lung) was significantly enriched in mutation-positive individuals, although nonneurological features were less frequent and their presence varied to a much higher extent. In line with literature, our analysis revealed a high rate of thyroid defects $(75 \%)$ with mild TSH elevation in the majority of patients. We detected a higher frequency of pulmonary disorder $(78 \%)$ than previously reported, with neonatal respiratory distress $(46 \%)$ and recurrent pneumonia with need for antibiotic treatment $(53 \%)$ as the prevailing features. The reasons for the organ-specific differences in response to NKX2-1 deficiency remain elusive, but some facts suggest that the lower tolerance towards NKX2-1 deregulation in brain might be connected to the postnatal function of NKX2-1 in this organ. NKX2-1 is expressed in brain throughout life, especially in cholinergic and GABAergic neurons of the basal ganglia, both in mice and human. ${ }^{53-55}$ Moreover, structural brain defects have not been described in NKX2-1 mutation-positive patients so far, and they are oligosymptomatic in the first years of their life. Importantly, NKX2-1-deficient patients in this cohort were predominantly not affected by epilepsy or severe mental retardation. This was unexpected given the phenotype of Nkx2-1-deficient mice with respect to cortical interneurons $^{5}$ and recent bioinformatic analysis predicting NKX2-1 as a candidate gene for epilepsy in humans. ${ }^{56}$

\section{New symptoms associated with NKX2-1 deficiency: abnormal height, cardiac septum defects and asthma}

Our comprehensive phenotypic characterisation revealed novel NKX2-1-associated hypothalamic symptoms, including frequent 
Figure 5 Additional symptoms in patients with NKX2-1 mutations. (A) Body height standard deviation score (SDS) values of detailed phenotype cohort. Median value -0.84 SDS; patients 1-18 carrying NKX2-1 mutations: 1, chr14:g (36042742_36142540)del; 2, chr14:g (36042742_36142540)del; 3, chr14:g (36042742_36142540)del; 4, chr14:g (35138127_37502915)del; 5, chr14:g (32446471_41666818)del; 6, chr14:g (31766511_46944545)del; 7, chr14:g (35883857_38226260)del; 8,

c.522C>G_p.Tyr174X; 9, c.522C>G_p. Tyr174X; 10, c.585nsGG_p. Leu195GlyfsX3; 11, c.613G>T_p. Val205Phe; 12, [c.608C >G] $+[c .613 G>T] \_[p . T h r 203 A r g]+[p$. Val205Phe]; 13, c.608C>G_p. Val205Phe; 14, c.608C>G_p. Val205Phe; 15, c.608C>G_p. Val205Phe; 16, c.338G>A_p.Trp113X; 17, c.261C>A_p.Cys87X; 18, c.261C>A_p.Cys87X; 19, c.506C>A_p. Ser169X; 20, c.157insC_p. Met53HisfsX355; 21, c.236C>A_p. Ser79X; 22, c.236C>A_p.Ser79X; 23, c.236C>A_p.Ser79X; 24, c.866_883delinsCTACA_p. Gln289ProfsX59; 25, c.793delA_p. Lys265LysfsX87;26, c.712delGG_p. Gly238ArgfsX170; 27, c.712delGG_p. Gly238ArgfsX170; 28, c.339delG_p. Trp113CysfsX16. (B) Heatmap summarising the results of detailed phenotyping in 18 index patients and 10 relatives with $N K X 2-1$ deficiency. The presence and absence of symptoms is indicated by yellow and blue boxes, respectively. Missing values are shown in grey. The first seven columns to the left depict the phenotypes of the patients affected by a copy number variant. Point mutations are sorted according to their genomic position. The letters (a), (b) and (c) heading the description of the mutation indicate family members sharing the same mutation.

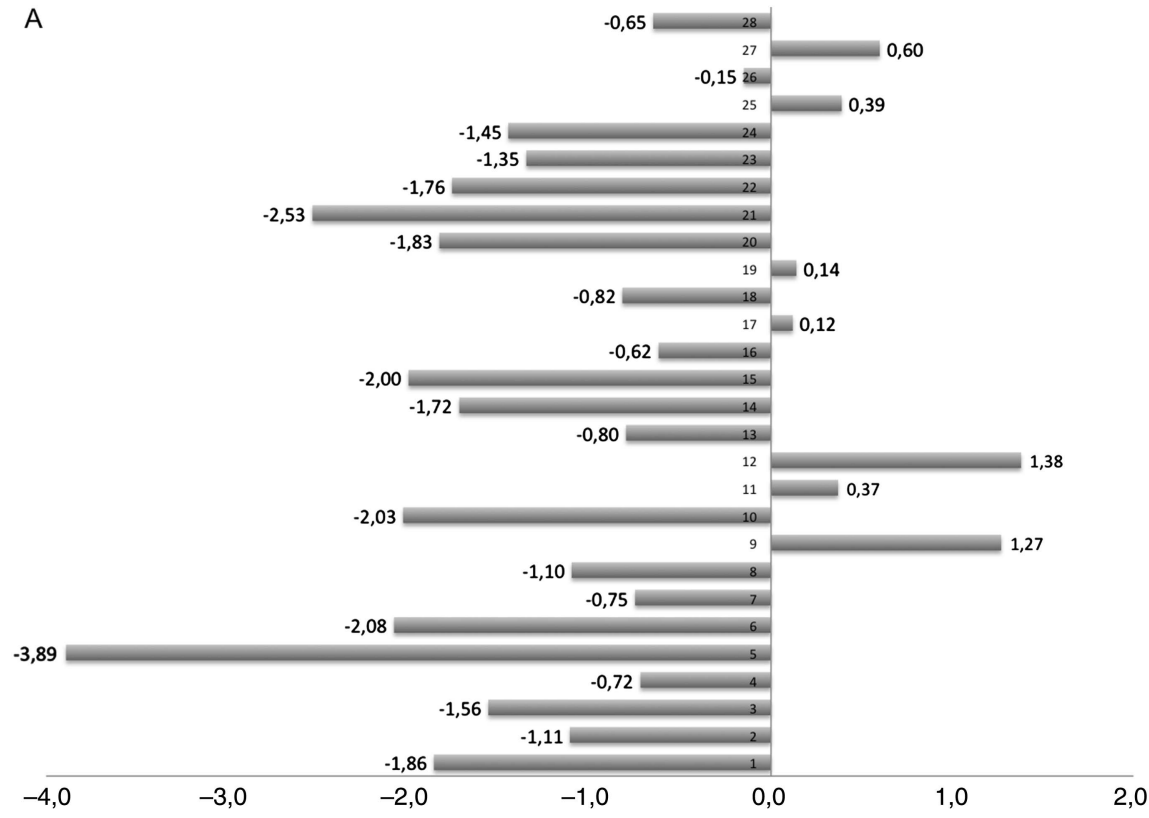

B

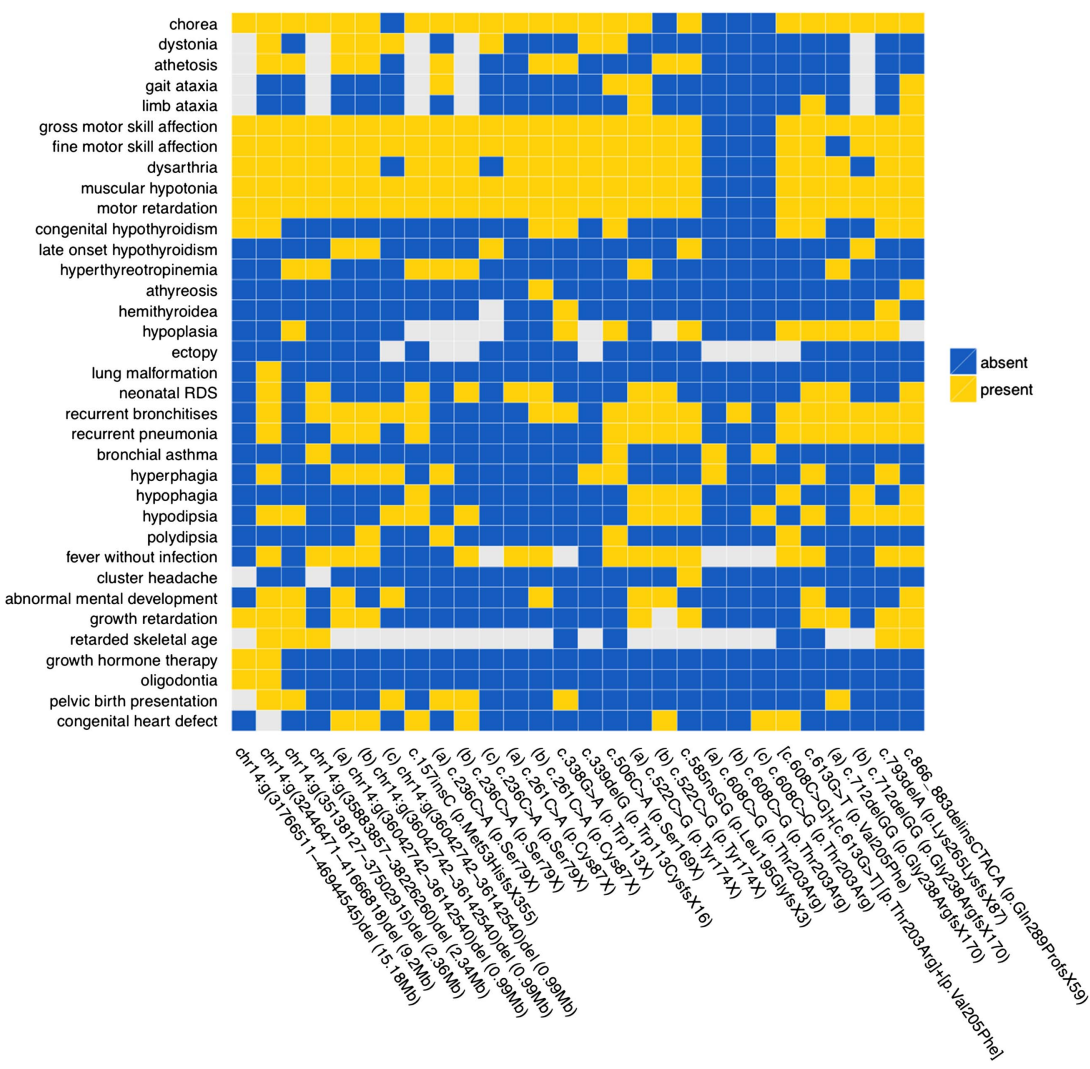

may reflect that proper heart development depends on normal thyroid hormone activity, for example, the postnatal surge of T3 levels, which normally triggers the switch from cardiac myosin heavy chain isoform MYH7 to MYH6 ${ }^{58}$ Mutations in MYH6 have already been identified in familial cases of atrial septum defects $^{59}$ ). However, cardiac defect frequency observed in NKX2-1 mutation-positive patients of this study is much higher than the reported prevalence in patients with thyroid malfunction without genotype-based stratification (7/28 vs 13.8 / $\left.1000^{57}{ }^{60}\right)$. Moreover, one patient included in this study presented with congenital heart defect in the absence of any thyroidal defect. Both observations point at a direct role of NKX2-1 
in heart development and the aetiology of cardiac septum defects, which is independent of thyroid hormone activity. This idea is supported by the fact that mutations in NKX2-5 have already been identified as a cause of ASD, and that both members of the NKX family share several direct and indirect downstream targets, including key regulators of heart development such as GATA4, GATA6 and HOP. ${ }^{61-63}$

There is accumulating evidence for a role of NKX2-1 in the development and progression of leukaemia, thyroid and bronchial carcinoma. ${ }^{64-69}$ Furthermore, an association of germline mutations and the development of neoplasiae, for example, multinodular goitre and papillary thyroid carcinoma, ${ }^{60}$ has been discussed. This may impact the use of congenital NKX2-1 mutations as a prognostic marker in future. In principle, the identification of congenital NKX2-1 mutations is a favourable result as it predicts that disease will hardly progress and it holds out the prospect that symptoms will improve at later stages of life. ${ }^{70} 71$ This positive aspect may be tarnished in future by uncertainties about an increased cancer risk that might be associated with congenital NKX2-1 mutations. Unfortunately, the young average age of patients in this study did not allow any conclusive assessment of cancer risk associated with congenital NKX2-1 mutations. However, one patient died of bronchial carcinoma at the age of 46 without having any history of smoking.

\section{Quality of mutations and their correlation to phenotype}

In line with previous studies, all intragenic point mutations identified in this study differ in position and quality. Thus, the exclusive clustering of missense mutations within the DNA binding homeodomain is unlikely to indicate a mutational hot spot, but rather reflects a lower tolerance towards single amino acid exchanges within the homeodomain compared with the surrounding transactivation domains. There, only nonsense or frame-shift mutations in the N-terminal part, and potentially also in the C-terminal part, ${ }^{37}$ can compromise protein functionality.

We have performed accurate phenotyping in index patients and their affected relatives. This enabled us to monitor the symptoms caused by the very same NKX2-1 mutation in different individuals. In general, intrafamiliar phenotypic variability was smaller than the variability between unrelated patients carrying different mutations (figure 5B). Neurological symptoms turned out to be the most consistent feature within families, while the intrafamiliar spectrum of thyroid and lung symptoms could range from no impairment at all to severe hypothyroidism with agenesis of the gland and severe neonatal respiratory distress, respectively.

Our family studies also highlighted the possible consequences of NKX2-1 mutations not altering its ability to bind to DNA. So far all mutations located within the homeodomain have shown loss of function due to interference with DNA binding. $8131521-252728$ Here we report the first variant within the homeodomain (p.Thr203Arg) that does not affect DNA binding capacity. The mutation was present on the maternal allele of an index patient, who also carried a second missense mutation (p.Arg205Phe) mapping to the homeodomain encoded on his paternal allele. As can be inferred from the structural homology model, which depicts the intercalation of homeodomain helices and DNA binding groove (figure 1C), the p.Thr203Arg variant neither seems to play a role in the stabilisation of the helix conformation nor to interact directly with DNA. In line with this assumption, and in contrast to the p.Arg205Phe mutation on the paternal allele, experimental validation by EMSA showed no deterioration of DNA binding capacity associated with the p.Thr203Arg variant.
Only the index patient who carried both mutations presented with the characteristic phenotype that is typically associated with NKX2-1 deficiency, including neurological symptoms. His three relatives, who solely carried the mutation that had no effect on DNA binding (p.Thr203Arg), lacked most of these symptoms, but not all. Congenital heart defect was diagnosed in one of the three relatives, asthma or recurrent bronchial infection was present in all of them. This observation can be interpreted in two ways: (i) only the second mutation (p.Arg205Phe) in the index patient is causative, while ASD and pulmonary problems in his relatives are not related to mutations in NKX2-1; or (ii) the mild pulmonary and cardiac symptoms are caused by impaired functionality of NKX2-1 that is not mediated by its DNA binding capacity. Although the observed haploinsufficiency of NKX2-1 argue in favour of the first hypothesis, there is also evidence in support of the second one. Minoo and colleagues recently discovered that the homeodomain of NKX2-1 physically interacts with FOXA1 in a DNA-independent manner in order to control the expression of surfactant protein C (SP-C) and Clara cell protein (Ccsp). ${ }^{72}$ Both $\mathrm{SpC}$ and Ccsp are essential for proper function of the lung, and their deregulation has already been implicated in the aetiology of asthma and recurrent pulmonary infections. ${ }^{73}$ In light of these facts, it is tempting to speculate that the characteristic NKX2-1 phenotype and its variability are not only attributed to impaired DNA binding, but are also a reflection of altered protein-protein interaction characteristics of NKX2-1, or more precisely, one of its isoforms. Thus, preservation of DNA binding capacity of mutated NKX2-1 alone may not be an eligible argument to rule out disease association. This may especially apply to those rare cases that lack neurological symptoms, including the recently described missense mutation p.Phe198Leu, where, unfortunately, its functional implications have not been investigated. ${ }^{75}$ Noteworthy, HOP, one of the shared downstream targets of NKX2-1 and NKX2-5 (see above), is a homeodomain protein that lacks any DNA binding potential. ${ }^{76}$

\section{CNVs outside of $N K X 2-1$ result in a phenotype similar to that of intragenic mutations}

Given the impact of DNA CNVs on the aetiology of congenital disorders, we have complemented our sequence analysis by testing patients negative for NKX2-1 point mutations by means of array CGH employing a high-resolution custom array. We have identified 10 novel heterozygous deletions. In line with previous reports, ${ }^{14} 16$ they all differed in size and position. This makes it unlikely that recurrence of NKX2-1 deletions is the consequence of a specific genomic architecture that renders this region particularly prone to rearrangements. Our data also corroborate the reported lack of correlation between $\mathrm{CNV}$ size, which ranges from $76 \mathrm{~kb}$ to $15.17 \mathrm{Mb}$ in our study, and severity of disease. ${ }^{14}$

Strikingly, two of the deletions did not encompass NKX2-1 at all. Similar observations have been made recently and have fuelled speculations that removal of regulatory elements downstream of NKX2-1 might produce a phenotype similar to intragenic loss. ${ }^{39} 77$ At least two prospective enhancer elements related to forebrain and thyroid function seem to exist with or in close proximity to the genomic interval encompassed by the two deletions identified in this study. ${ }^{78} 79$ For one of these conserved sequences, a forebrain expression has already been shown (http://enhancer.lbl.gov/cgi-bin/ imagedb3.pl?form = presentation\&show $=1$ \&experiment_id $=1538$ \&organism_id=1) and the other one has been highlighted as potential enhancer by a recent meta-analysis of GWAS data related to thyroid function and TSH levels. ${ }^{79}$ Unfortunately, re-evaluation of public data on higher-order chromatin organisation and CTCF 
binding, a protein involved in DNA looping, did not reveal any particular chromosome conformation that conclusively indicates any connections of NKX2-1 with a specific regulatory element in this region $^{80-82}$ (see online supplementary figure S5). Nevertheless, there seems to exist selective pressure to keep NKX2-1 in next proximity to the interval deleted in the two patients as this region, together with NKX2-1, is part of one of the largest blocks of synteny in humans ${ }^{83}$ and also represents the core region of the recurrent amplicon reported in thyroid and bronchial carcinomas. ${ }^{64-66}$ However, synteny and co-amplification could also signal the presence of genes, whose co-regulation with NKX2-1 is essential for proper development and function of brain, thyroid and lung. Proceeding on this assumption, distortion of the fine-tuned stoichiometry of their products could mimic an NKX2-1 deficiency like phenotype. Two genes recently discussed in the context of CNVs outside NKX2-1 are NPAS3 and RALGAPA1. ${ }^{77}$ Malfunction of these two genes can lead to respiratory distress and cognitive disorders, respectively. Yet, both genes are not mapping within the commonly deleted region of the two cases from our study. The only gene mapping to this interval is MBIP (MAP3K12 binding inhibitory protein 1), which encodes a component of the ATAC (Ada Two-A containing) complex. This histone acetyltransferase complex is supposed to translate extracellular cues into chromatin modifications and consequently altered gene expression. ${ }^{84}$ Interrogation of protein interaction databases by means of String $9.05^{85}$ and literature mining did not reveal apparent commonalities between MBIP and NKX2-1, apart from the fact that both proteins are-directly or indirectly- involved in the regulation of protein acetylation. In order to elucidate more information on possible functional connections between the two proteins, we have evaluated expression patterns of Mbip in mouse embryos at embryonic day 11.5. In situ hybridisation revealed that the Mbip expression pattern spatially and temporally coincides with that of Nkx2-1, for example, in the thyroid anlage, lung and forebrain (figure $3 \mathrm{C}$ ). This fits to the recent description of Mbip expression in progenitor cells of the murine lateral ganglionic eminence, ${ }^{46}$ which is also known as the major expression domain of $\mathrm{Nkx} 2-1$ in the forebrain at the same stage of embryonic development. ${ }^{4} 53$ This coincidence renders deregulation of MBIP a plausible cause of a NKX2-1 deficiency like phenotype and has prompted us to sequence $M B I P$ in those 74 patients of our cohort, who were negative for NKX2-1 mutations. In contrast to what would have been expected under the assumption of a causative role of $M B I P$ for this phenotype, no single mutation was identified in this gene.

In summary, our study expands the phenotypic spectrum recurrently associated with NKX2-1 deficiency, with some of the symptoms maybe not exclusively linked to alterations of DNA binding capacity of this transcription factor. In our view, the high incidence of NKX2-1 mutations justifies the regular molecular screening in corresponding patients in order to distinguish them from others with resembling phenotypes at early stages of disease, but considerable different outcomes. However, these diagnostic efforts should not be confined to the gene itself, but should also comprise the analysis of regulatory elements and interaction partners of NKX2-1.

\footnotetext{
Author affiliations

${ }^{1}$ Institute for Experimental Pediatric Endocrinology, Charité University Medicine, Berlin, Germany

${ }^{2}$ Max Planck Institute for Molecular Genetics, Berlin, Germany

${ }^{3}$ Department of Neonatology, Charité University Medicine, Berlin, Germany

${ }^{4}$ Department of Neurology, Charité University Medicine, Berlin, Germany

${ }^{5}$ Department of Neuropediatrics, Charité University Medicine, Berlin, Germany

${ }^{6}$ Neuromuscular and Neurogenetic Disorders of Childhood Section, National Institute

of Neurological Disorders and Stroke, NIH, Bethesda, Maryland, USA
}

${ }^{7}$ Interdisciplinary Pediatric Center for Children with Developmental Disabilities and Severe Chronic Disorders, University Medical Center, Georg August University, Göttingen, Germany

${ }^{8}$ Department for Neuropediatrics, Children's and Youth Hospital "Auf der Bult", Hannover, Germany

${ }^{9}$ Division of Pediatric Endocrinology \& Diabetes, John Hunter Children's Hospital, Newcastle, Australia

${ }^{10}$ Department of Woman and Child, University of Leuven, Leuven, Belgium

${ }^{11}$ Dr. von Haunersches Kinderspital, Member of the German Center for Lung

Research, University of Munich, Munich, Germany

${ }^{12}$ Division of Endocrinology \& Diabetes, Royal Children's Hospital Melbourne,

Melbourne, Australia

${ }^{13}$ Department of Clinical Sciences- Pediatric Endocrinology, University Hospital MAS, Malmö, Sweden

${ }^{14}$ Department of Pediatric and Adolescent Medicine, Medical University of Innsbruck, Innsbruck, Austria

${ }^{15}$ Division of Child Neurology, University Childrens Hospital Zurich, Zurich, Switzerland

${ }^{16}$ Department for Neuropediatrics, Heidelberg University Hospital, Heidelberg, Germany

${ }^{17}$ Department of Paediatric Endocrinology Screening and Functional Endocrine Diagnostics, University Paediatric Hospital, Medical University Sofia, Sofia, Bulgaria

Correction notice This article has been corrected since it was published Online First. The second corresponding author is now included and Markus Schuelke name has been updated.

\section{Acknowledgements We thank all the patients and their families for their cooperation and support.}

Contributors Genotyping experiments and analysis (Sanger sequencing and array (GH) as well as preparation of figures were done by AT. Extended phenotype data collection and analysis was carried out by SS-H. Further experimental data were generated by PS (mouse embryonic hybridisation experiments). IM and SJ (technical assistance on array CGH and Sanger sequencing), CD (EMSA experiments), HB (Mini Gene Reporter Assay \& Cell Transfection experiments) and GK (NKX2-1 structural homology model). Furthermore, JK and MS assisted on analysis of extended phenotype data. $\mathrm{GE}, \mathrm{AS}$ and $\mathrm{H}-\mathrm{HR}$ contributed to interpretation of data and $\mathrm{AG}$ to study design, respectively. $\mathrm{CB}, \mathrm{KB}, \mathrm{H}-\mathrm{JC}, \mathrm{PC}, \mathrm{FZ}, \mathrm{MG}, \mathrm{JH}, \mathrm{SI}, \mathrm{CH}, \mathrm{KK}, \mathrm{BP}, \mathrm{DR}$ and IS did patients' phenotyping and sample collection. AT, RU and HK designed the study, interpreted data and wrote the manuscript, and are therefore the guarantors of the work.

\section{Competing interests None.}

Patient consent Obtained.

Ethics approval Institutional Review Board of Charité, University Medicine Berlin.

Provenance and peer review Not commissioned; externally peer reviewed.

\section{REFERENCES}

1 Kim Y, Nirenberg M. Drosophila NK-homeobox genes. Proc Natl Acad Sci USA 1989;86:7716-20.

2 Guazzi S, Price M, De Felice M, Damante G, Mattei MG, Di Lauro R. Thyroid nuclear factor 1 (TTF-1) contains a homeodomain and displays a novel DNA binding specificity. EMBO J 1990;9:3631-9.

3 Mizuno K, Gonzalez FJ, Kimura S. Thyroid-specific enhancer-binding protein (T/EBP): cDNA cloning, functional characterization, and structural identity with thyroid transcription factor TTF-1. Mol Cell Biol 1991;11:4927-33.

4 Kimura S, Hara Y, Pineau T, Fernandez-Salguero P, Fox CH, Ward JM, Gonzalez FJ. The T/ebp null mouse: thyroid-specific enhancer-binding protein is essential for the organogenesis of the thyroid, lung, ventral forebrain, and pituitary. Genes Dev 1996:10:60-9.

5 Sussel L, Marin 0, Kimura S, Rubenstein JL. Loss of Nkx2.1 homeobox gene function results in a ventral to dorsal molecular respecification within the basal telencephalon: evidence for a transformation of the pallidum into the striatum. Development 1999;126:3359-70.

6 Devriendt K, Vanhole C, Matthijs G, de Zegher F. Deletion of thyroid transcription factor-1 gene in an infant with neonatal thyroid dysfunction and respiratory failure. N Engl J Med 1998:338:1317-18.

7 Iwatani N, Mabe H, Devriendt K, Kodama M, Miike T. Deletion of NKX2.1 gene encoding thyroid transcription factor- 1 in two siblings with hypothyroidism and respiratory failure. J Pediatr 2000;137:272-6.

8 Krude $H$, Schutz B, Biebermann $H$, von Moers A, Schnabel D, Neitzel $H$, Tonnies $H$, Weise D, Lafferty A, Schwarz S, DeFelice M, von Deimling A, van Landeghem F, DiLauro R, Gruters A. Choreoathetosis, hypothyroidism, and pulmonary alterations due to human NKX2-1 haploinsufficiency. J Clin Invest 2002;109:475-80.

9 Pohlenz J, Dumitrescu A, Zundel D, Martine U, Schonberger W, Koo E, Weiss RE, Cohen RN, Kimura S, Refetoff S. Partial deficiency of thyroid transcription factor 1 
produces predominantly neurological defects in humans and mice. J Clin Invest 2002;109:469-73.

10 Breedveld GJ, van Dongen JW, Danesino C, Guala A, Percy AK, Dure LS, Harper P, Lazarou LP, van der Linde $H$, Joosse $M$, Gruters $A$, MacDonald ME, de Vries BB, Arts WF, Oostra BA, Krude H, Heutink P. Mutations in TITF-1 are associated with benign hereditary chorea. Hum Mol Genet 2002;11:971-9.

11 Petek E, Plecko-Startinig B, Windpassinger C, Egger H, Wagner K, Kroisel PM. Molecular characterisation of a $3.5 \mathrm{Mb}$ interstitial $14 \mathrm{q}$ deletion in a child with several phenotypic anomalies. J Med Genet A 2003;40:e47.

12 Devos D, Vuillaume I, de Becdelievre A, de Martinville B, Dhaenens CM, Cuvellier JC, Cuisset JM, Vallee L, Lemaitre MP, Bourteel H, Hachulla E, Wallaert B, Destee A, Defebvre L, Sablonniere B. New syndromic form of benign hereditary chorea is associated with a deletion of TITF-1 and PAX-9 contiguous genes. Mov Disord 2006:21:2237-40.

13 Carre A, Szinnai G, Castanet M, Sura-Trueba S, Tron E, Broutin-L'Hermite I, Barat P, Goizet C, Lacombe D, Moutard ML, Raybaud C, Raynaud-Ravni C, Romana S, Ythier $\mathrm{H}$, Leger J, Polak M. Five new TTF1/NKX2.1 mutations in brain-lung-thyroid syndrome: rescue by PAX8 synergism in one case. Hum Mol Genet 2009;18:2266-76.

14 Teissier R, Guillot L, Carre A, Morandini M, Stuckens C, Ythier H, Munnich A, Szinnai G, de Blic J, Clement A, Leger J, Castanet M, Epaud R, Polak M. Multiplex Ligation-dependent Probe Amplification improves the detection rate of NKX2.1 mutations in patients affected by brain-lung-thyroid syndrome. Horm Res Paediatr 2012;77:146-51

15 Gras D, Jonard L, Roze E, Chantot-Bastaraud S, Koht J, Motte J, Rodriguez D, Louha M, Caubel I, Kemlin I, Lion-Francois L, Goizet C, Guillot L, Moutard ML, Epaud R, Heron B, Charles P, Tallot M, Camuzat A, Durr A, Polak M, Devos D, Sanlaville D, Vuillaume I, Billette de Villemeur T, Vidailhet M, Doummar D. Benign hereditary chorea: phenotype, prognosis, therapeutic outcome and long term follow-up in a large series with new mutations in the TITF1/NKX2-1 gene. J Neurol Neurosurg Psychiatry 2012;83:956-62.

16 Santen GW, Sun Y, Giisbers AC, Carre A, Holvoet M, Haeringen A, Lesnik Oberstein SA, Tomoda A, Mabe H, Polak M, Devriendt K, Ruivenkamp CA, Biilsma EK. Further delineation of the phenotype of chromosome 14q13 deletions: (positional) involvement of FOXG1 appears the main determinant of phenotype severity, with no evidence for a holoprosencephaly locus. J Med Genet A 2012;49:366-72.

17 Willemsen MA, Breedveld GJ, Wouda S, Otten BJ, Yntema JL, Lammens M, de Vries BB. Brain-Thyroid-Lung syndrome: a patient with a severe multi-system disorder due to a de novo mutation in the thyroid transcription factor 1 gene. Eur $J$ Pediatr 2005;164:28-30.

18 Moya CM, Perez de Nanclares G, Castano L, Potau N, Bilbao JR, Carrascosa A, Bargada M, Coya R, Martul P, Vicens-Calvet E, Santisteban P. Functional study of a novel single deletion in the TITF1/NKX2.1 homeobox gene that produces congenital hypothyroidism and benign chorea but not pulmonary distress. J Clin Endocrinol Metab 2006;91:1832-41.

19 Nagasaki K, Narumi S, Asami T, Kikuchi T, Hasegawa T, Uchiyama M. Mutation of a gene for thyroid transcription factor-1 (TITF1) in a patient with clinical features of resistance to thyrotropin. Endocr J 2008;55:875-8.

20 Kleinlein B, Griese M, Liebisch G, Krude H, Lohse P, Aslanidis C, Schmitz G, Peters J, Holzinger A. Fatal neonatal respiratory failure in an infant with congenital hypothyroidism due to haploinsufficiency of the NKX2-1 gene: alteration of pulmonary surfactant homeostasis. Arch Dis Child 2010

21 Nettore IC, Ferrara AM, Mirra P, Sibilio A, Pagliara V, Kamoi Kay CS, Lorenzoni PJ, Werneck LC, Bruck I, Coutinho Dos Santos LH, Beguinot F, Salvatore D, Ungaro P, Fenzi G, Scola RH, Macchia PE. Identification and functional characterization of a novel mutation in the NKX2-1 gene: comparison with the data in the literature. Thyroid 2013;23:675-82.

22 Asmus F, Horber V, Pohlenz J, Schwabe D, Zimprich A, Munz M, Schoning M, Gasser T. A novel TITF-1 mutation causes benign hereditary chorea with response to levodopa. Neurology 2005;64:1952-4.

23 do Carmo Costa M, Costa C, Silva AP, Evangelista P, Santos L, Ferro A, Sequeiros J, Maciel P. Nonsense mutation in TITF1 in a Portuguese family with benign hereditary chorea. Neurogenetics 2005;6:209-15.

24 Provenzano C, Veneziano L, Appleton R, Frontali M, Civitareale D. Functional characterization of a novel mutation in TITF-1 in a patient with benign hereditary chorea. J Neurol Sci 2008;264:56-62.

25 Glik A, Vuillaume I, Devos D, Inzelberg R. Psychosis, short stature in benign hereditary chorea: a novel thyroid transcription factor-1 mutation. Mov Disord 2008:23:1744-7.

26 Ferrara AM, De Michele G, Salvatore E, Di Maio L, Zampella E, Capuano S, De Prete G, Rossi G, Fenzi G, Filla A, Macchia PE. A novel NKX2.1 mutation in a family with hypothyroidism and benign hereditary chorea. Thyroid 2008;18:1005-9.

27 Maquet E, Costagliola S, Parma J, Christophe-Hobertus C, Oligny LL, Fournet JC, Robitaille Y, Vuissoz IM, Payot A, Laberge S, Vassart G, Van Vliet G, Deladoey J. Lethal respiratory failure and mild primary hypothyroidism in a term girl with a de novo heterozygous mutation in the TITF1/NKX2.1 gene. I Clin Endocrinol Metab 2009:94:197-203.
28 Gillett ES, Deutsch GH, Bamshad MJ, McAdams RM, Mann PC. Novel NKX2.1 mutation associated with hypothyroidism and lethal respiratory failure in a full-term neonate. J Perinatol 2013:33:157-60.

29 Kleiner-Fisman G, Rogaeva E, Halliday W, Houle S, Kawarai T, Sato C, Medeiros H, St George-Hyslop PH, Lang AE. Benign hereditary chorea: clinical, genetic, and pathological findings. Ann Neurol 2003;54:244-7.

30 Doyle DA, Gonzalez I, Thomas B, Scavina M. Autosomal dominant transmission of congenital hypothyroidism, neonatal respiratory distress, and ataxia caused by a mutation of NKX2-1. J Pediatr 2004;145:190-3.

31 Asmus F, Devlin A, Munz M, Zimprich A, Gasser T, Chinnery PF. Clinical differentiation of genetically proven benign hereditary chorea and myoclonus-dystonia. Mov Disord 2007;22:2104-9.

32 Hamvas A, Deterding RR, Wert SE, White FV, Dishop MK, Alfano DN, Halbower AC, Planer B, Stephan MJ, Uchida DA, Williames LD, Rosenfeld JA, Lebel RR, Young LR, Cole FS, Nogee LM. Heterogeneous Pulmonary Phenotypes Associated With Mutations in the Thyroid Transcription Factor Gene NKX2-1. Chest 2013;144:794-804.

33 Salerno T, Peca D, Menchini L, Schiavino A, Petreschi F, Occasi F, Cogo P, Danhaive $\mathrm{O}$, Cutrera R. Respiratory insufficiency in a newborn with congenital hypothyroidism due to a new mutation of TTF-1/NKX2.1 gene. Pediatr Pulmonol 2013:49:E42-4

34 Stockton DW, Das P, Goldenberg M, D'Souza RN, Patel PI. Mutation of PAX9 is associated with oligodontia. Nat Genet 2000;24:18-19.

35 Devos H, Rodd C, Gagne N, Laframboise R, Van Vliet G. A search for the possible molecular mechanisms of thyroid dysgenesis: sex ratios and associated malformations. J Clin Endocrinol Metab 1999;84:2502-6.

36 Guala A, Falco V, Breedveld G, De Filippi P, Danesino C. Deletion of PAX9 and oligodontia: a third family and review of the literature. Int J Paediatr Dent 2008:18:441-5.

37 Silberschmidt $D$, Rodriguez-Mallon A, Mithboakar P, Cali G, Amendola E, Sanges $R_{\iota}$ Zannini M, Scarfo M, De Luca P, Nitsch L, Di Lauro R, De Felice M. In vivo role of different domains and of phosphorylation in the transcription factor Nkx2-1. BMC Dev Biol 2011;1:9.

38 Inzelberg R, Weinberger M, Gak E. Benign hereditary chorea: an update. Parkinsonism Relat Disord 2011:17:301-7.

39 Dale RC, Grattan-Smith P, Nicholson M, Peters GB. Microdeletions detected using chromosome microarray in children with suspected genetic movement disorders: a single-centre study. Dev Med Child Neurol 2012;54:618-23.

40 Esposito G, Fogolari F, Damante G, Formisano S, Tell G, Leonardi A, Di Lauro R, Viglino $P$. Analysis of the solution structure of the homeodomain of rat thyroid transcription factor 1 by $1 \mathrm{H}-\mathrm{NMR}$ spectroscopy and restrained molecular mechanics. Eur J Biochem/FEBS 1996:241:101-13.

41 Al Taji E, Biebermann H, Limanova Z, Hnikova O, Zikmund J, Dame C, Gruters A, Lebl J, Krude H. Screening for mutations in transcription factors in a Czech cohort of 170 patients with congenital and early-onset hypothyroidism: identification of a novel PAX8 mutation in dominantly inherited early-onset non-autoimmune hypothyroidism. Eur J Endocrinol 2007;156:521-9.

42 Dame C, Sola MC, Lim KC, Leach KM, Fandrey J, Ma Y, Knopfle G, Engel JD, Bungert J. Hepatic erythropoietin gene regulation by GATA-4. J Biol Chem 2004;279:2955-61.

43 Civitareale D, Lonigro R, Sinclair AJ, Di Lauro R. A thyroid-specific nuclear protein essential for tissue-specific expression of the thyroglobulin promoter. EMBO $\mathrm{J}$ 1989:8:2537-42.

44 de Sanctis L, Corrias A, Romagnolo D, Di Palma T, Biava A, Borgarello G, Gianino P, Silvestro L, Zannini M, Dianzani I. Familial PAX8 small deletion (c.989_992delACCC) associated with extreme phenotype variability. J Clin Endocrinol Metab 2004;89:5669-74.

45 Musti AM, Avvedimento EV, Polistina C, Ursini VM, Obici S, Nitsch L, Cocozza S, Di Lauro R. The complete structure of the rat thyroglobulin gene. Proc Natl Acad Sci USA 1986;83:323-7.

46 Tucker ES, Segall S, Gopalakrishna D, Wu Y, Vernon M, Polleux F, Lamantia AS. Molecular specification and patterning of progenitor cells in the lateral and medial ganglionic eminences. J Neurosci 2008;28:9504-18.

47 Brent AE, Schweitzer R, Tabin CJ. A somitic compartment of tendon progenitors. Cell 2003;113:235-48.

48 Dessau RB, Pipper CB. ["R"--project for statistical computing]. Ugeskr Laeger 2008; 170:328-30.

49 Antonica F, Kasprzyk DF, Opitz R, lacovino M, Liao XH, Dumitrescu AM, Refetoff S, Peremans K, Manto M, Kyba M, Costagliola S. Generation of functional thyroid from embryonic stem cells. Nature 2012;491:66-71.

50 Lapi P, Macchia PE, Chiovato L, Biffali E, Moschini L, Larizza D, Baserga M Pinchera $A$, Fenzi $G$, Di Lauro R. Mutations in the gene encoding thyroid transcription factor-1 (TTF-1) are not a frequent cause of congenital hypothyroidism (CH) with thyroid dysgenesis. Thyroid 1997;7:383-7.

51 Perna MG, Civitareale D, De Filippis V, Sacco M, Cisternino C, Tassi V. Absence of mutations in the gene encoding thyroid transcription factor-1 (TTF-1) in patients with thyroid dysgenesis. Thyroid 1997:7:377-81.

52 Hishinuma A, Kuribayashi T, Kanno Y, Onigata K, Nagashima K, leiri T. Sequence analysis of thyroid transcription factor- 1 gene reveals absence of mutations in 
patients with thyroid dysgenesis but presence of polymorphisms in the $5^{\prime}$ flanking region and intron. Endocr J 1998;45:563-7.

53 Germain ND, Banda EC, Becker S, Naegele JR, Grabel LB. Derivation and isolation of NKX2.1-positive basal forebrain progenitors from human embryonic stem cells. Stem Cells Dev 2013:22:1477-89.

54 Niquille M, Minocha S, Hornung JP, Rufer N, Valloton D, Kessaris N, Alfonsi F, Vitalis T, Yanagawa Y, Devenoges C, Dayer A, Lebrand C. Two specific populations of GABAergic neurons originating from the medial and the caudal ganglionic eminences aid in proper navigation of callosal axons. Dev Neurobiol 2013:73:647-72

55 Zhao Y, Flandin P, Vogt D, Blood A, Hermesz E, Westphal H, Rubenstein J. Ldb1 is essential for development of Nkx2.1 lineage derived GABAergic and cholinergic neurons in the telencephalon. Dev Biol 2013;385:94-106.

56 Woods JO, Singh-Blom UM, Laurent JM, McGary KL, Marcotte EM. Prediction of gene-phenotype associations in humans, mice, and plants using phenologs. BMC Bioinformatics 2013;14:203.

57 Olivieri A, Stazi MA, Mastroiacovo P, Fazzini C, Medda E, Spagnolo A, De Angelis S, Grandolfo ME, Taruscio D, Cordeddu V, Sorcini M. A population-based study on the frequency of additional congenital malformations in infants with congenital hypothyroidism: data from the Italian Registry for Congenital Hypothyroidism (1991-1998). J Clin Endocrinol Metab 2002;87:557-62.

58 van Tuyl M, Blommaart PE, de Boer PA, Wert SE, Ruijter JM, Islam S, Schnitzer J, Ellison AR, Tibboel D, Moorman AF, Lamers WH. Prenatal exposure to thyroid hormone is necessary for normal postnatal development of murine heart and lungs. Dev Biol 2004;272:104-17.

59 Ching YH, Ghosh TK, Cross SJ, Packham EA, Honeyman L, Loughna S, Robinson TE, Dearlove AM, Ribas G, Bonser AJ, Thomas NR, Scotter AJ, Caves LS, Tyrrell GP, Newbury-Ecob RA, Munnich A, Bonnet D, Brook JD. Mutation in myosin heavy chain 6 causes atrial septal defect. Nat Genet 2005;37:423-8.

60 Ngan ES, Lang BH, Liu T, Shum CK, So MT, Lau DK, Leon TY, Cherny SS, Tsai SY, Lo CY, Khoo US, Tam PK, Garcia-Barcelo MM. A germline mutation (A339 V) in thyroid transcription factor-1 (TITF-1/NKX2.1) in patients with multinodular goiter and papillary thyroid carcinoma. J Natl Cancer Inst 2009;101:162-75.

61 Zhang Y, Rath N, Hannenhalli S, Wang Z, Cappola T, Kimura S, Atochina-Vasserman E, Lu MM, Beers MF, Morrisey EE. GATA and Nkx factors synergistically regulate tissue-specific gene expression and development in vivo. Development 2007;134:189-98.

62 Trivedi CM, Zhu W, Wang Q, Jia C, Kee HJ, Li L, Hannenhalli S, Epstein JA. Hopx and Hdac2 interact to modulate Gata4 acetylation and embryonic cardiac myocyte proliferation. Dev Cell 2010;19:450-9.

63 Brewer AC, Alexandrovich A, Mjaatvedt CH, Shah AM, Patient RK, Pizzey JA. GATA factors lie upstream of Nkx 2.5 in the transcriptional regulatory cascade that effects cardiogenesis. Stem Cells Dev 2005;14:425-39.

64 Weir BA, Woo MS, Getz G, Perner S, Ding L, Beroukhim R, Lin WM, Province MA, Kraja A, Johnson LA, Shah K, Sato M, Thomas RK, Barletta JA, Borecki IB, Broderick S, Chang AC, Chiang DY, Chirieac LR, Cho J, Fujii Y, Gazdar AF, Giordano T, Greulich H, Hanna M, Johnson BE, Kris MG, Lash A, Lin L, Lindeman N, Mardis ER, McPherson JD, Minna JD, Morgan MB, Nadel M, Orringer MB, Osborne JR, Ozenberger B, Ramos AH, Robinson J, Roth JA, Rusch V, Sasaki H, Shepherd F, Sougnez C, Spitz MR, Tsao MS, Twomey D, Verhaak RG, Weinstock GM, Wheeler DA, Winckler W, Yoshizawa A, Yu S, Zakowski MF, Zhang Q, Beer DG, Wistuba II, Watson MA, Garraway LA, Ladanyi M, Travis WD, Pao W, Rubin MA Gabriel SB, Gibbs RA, Varmus HE, Wilson RK, Lander ES, Meyerson M. Characterizing the cancer genome in lung adenocarcinoma. Nature 2007:450:893-8.

65 Kendall J, Liu Q, Bakleh A, Krasnitz A, Nguyen KC, Lakshmi B, Gerald WL, Powers S, Mu D. Oncogenic cooperation and coamplification of developmental transcription factor genes in lung cancer. Proc Natl Acad Sci U S A 2007;104:16663-8.

66 Homminga I, Pieters R, Langerak AW, de Rooi JJ, Stubbs A, Verstegen M, Vuerhard M, Buijs-Gladdines J, Kooi C, Klous P, van Vlierberghe P, Ferrando AA, Cayuela JM, Verhaaf B, Beverloo HB, Horstmann M, de Haas V, Wiekmeijer AS, Pike-Overzet K, Staal FJ, de Laat W, Soulier J, Sigaux F, Meijerink JP. Integrated Transcript and Genome Analyses Reveal NKX2-1 and MEF2C as Potential Oncogenes in T Cell Acute Lymphoblastic Leukemia. Cancer Cell 2011;19:484-97.

67 Fabbro D, Di Loreto C, Beltrami CA, Belfiore A, Di Lauro R, Damante G. Expression of thyroid-specific transcription factors TTF-1 and PAX-8 in human thyroid neoplasms. Cancer Res 1994;54:4744-9.

68 Gudmundsson J, Sulem P, Gudbjartsson DF, Jonasson JG, Sigurdsson A, Bergthorsson JT, He H, Blondal T, Geller F, Jakobsdottir M, Magnusdottir DN Matthiasdottir S, Stacey SN, Skarphedinsson OB, Helgadottir H, Li W, Nagy R, Aguillo E, Faure E, Prats E, Saez B, Martinez M, Eyjolfsson Gl, Bjornsdottir US, Holm H, Kristjansson K, Frigge ML, Kristvinsson H, Gulcher JR, Jonsson T, Rafnar T, Hjartarsson H, Mayordomo Jl, de la Chapelle A, Hrafnkelsson J, Thorsteinsdottir U, Kong A, Stefansson K. Common variants on 9q22.33 and 14q13.3 predispose to thyroid cancer in European populations. Nat Genet 2009;41:460-4.

69 Matsuse M, Mitsutake N, Tanimura S, Ogi T, Nishihara E, Hirokawa M, Fuziwara CS, Saenko VA, Suzuki K, Miyauchi A, Yamashita S. Functional characterization of the novel BRAF complex mutation, BRAF(V600delinsYM) identified in papillary thyroid carcinoma. Int I Cancer 2013;132:738-43.

70 Fernandez M, Raskind W, Matsushita M, Wolff J, Lipe H, Bird T. Hereditary benign chorea: clinical and genetic features of a distinct disease. Neurology 2001;57:106-10.

71 Kleiner-Fisman G, Lang AE. Benign hereditary chorea revisited: A journey to understanding. Mov Disord 2007;22:2297-305.

72 Minoo P, Hu L, Xing Y, Zhu NL, Chen H, Li M, Borok Z, Li C. Physical and functional interactions between homeodomain NKX2.1 and winged helix/forkhead FOXA1 in lung epithelial cells. Mol Cell Biol 2007;27:2155-65.

73 Ku MS, Sun HL, Lu KH, Sheu JN, Lee HS, Yang SF, Lue KH. The CC16 A38G polymorphism is associated with the development of asthma in children with allergic rhinitis. Clin Exp Allergy 2011;41:794-800.

74 Puthothu B, Krueger M, Heinze J, Forster J, Heinzmann A. Haplotypes of surfactant protein $C$ are associated with common paediatric lung diseases. Pediatr Allergy Immunol 2006;17:572-7.

75 Hamvas A, Deterding RR, Wert SE, White FV, Dishop MK, Alfano DN, Halbower AC, Planer B, Stephan MJ, Uchida DA, Williames LD, Rosenfeld JA, Lebel RR, Young LR, Cole FS, Nogee LM. Heterogeneous pulmonary phenotypes associated with mutations in the thyroid transcription factor gene NKX2-1. Chest 2013:144:794-804.

76 Yin Z, Gonzales L, Kolla V, Rath N, Zhang Y, Lu MM, Kimura S, Ballard PL, Beers MF, Epstein JA, Morrisey EE. Hop functions downstream of Nkx2.1 and GATA6 to mediate HDAC-dependent negative regulation of pulmonary gene expression. Am J Physiol Lung Cell Mol Physiol 2006;291:L191-9.

77 Barnett CP, Mencel JJ, Gecz J, Waters W, Kirwin SM, Vinette KM, Uppill M, Nicholl J. Choreoathetosis, congenital hypothyroidism and neonatal respiratory distress syndrome with intact NKX2-1. Am J Med Genet A 2012;158A: 3168-73.

78 Pennacchio LA, Ahituv N, Moses AM, Prabhakar S, Nobrega MA, Shoukry M, Minovitsky S, Dubchak I, Holt A, Lewis KD, Plajzer-Frick I, Akiyama J, De Val S, Afzal V, Black BL, Couronne O, Eisen MB, Visel A, Rubin EM. In vivo enhancer analysis of human conserved non-coding sequences. Nature 2006;444:499-502.

79 Porcu E, Medici M, Pistis G, Volpato CB, Wilson SG, Cappola AR, Bos SD, Deelen J, den Heijer M, Freathy RM, Lahti J, Liu C, Lopez LM, Nolte IM, O'Connell JR, Tanaka T, Trompet S, Arnold A, Bandinelli S, Beekman M, Bohringer S, Brown SJ, Buckley BM, Camaschella C, de Craen AJ, Davies G, de Visser MC, Ford I, Forsen T, Frayling TM, Fugazzola L, Gogele M, Hattersley AT, Hermus AR, Hofman A, Houwing-Duistermaat JJ, Jensen RA, Kajantie E, Kloppenburg M, Lim EM, Masciullo C, Mariotti S, Minelli C, Mitchell BD, Nagaraja R, Netea-Maier RT, Palotie A, Persani L, Piras MG, Psaty BM, Raikkonen K, Richards JB, Rivadeneira F, Sala C, Sabra MM, Sattar N, Shields BM, Soranzo N, Starr JM, Stott DJ, Sweep FC, Usala $G$, van der Klauw MM, van Heemst $D$, van Mullem $A$, Vermeulen $S H$, Visser WE, Walsh JP, Westendorp RG, Widen E, Zhai G, Cucca F, Deary IJ, Eriksson JG, Ferrucci L, Fox CS, Jukema JW, Kiemeney LA, Pramstaller PP, Schlessinger D, Shuldiner AR, Slagboom EP, Uitterlinden AG, Vaidya B, Visser TJ, Wolffenbuttel BH, Meulenbelt I, Rotter II, Spector TD, Hicks AA, Toniolo D, Sanna S, Peeters RP, Naitza S. A meta-analysis of thyroid-related traits reveals novel loci and gender-specific differences in the regulation of thyroid function. PLOS genetics 2013;9:e1003266

80 Zhou X, Maricque B, Xie M, Li D, Sundaram V, Martin EA, Koebbe BC, Nielsen C, Hirst M, Farnham P, Kuhn RM, Zhu J, Smirnov I, Kent WJ, Haussler D, Madden PA Costello JF, Wang T. The Human Epigenome Browser at Washington University. Nat Methods 2011:8:989-90.

81 Wang H, Maurano MT, Qu H, Varley KE, Gertz J, Pauli F, Lee K, Canfield T, Weaver M, Sandstrom R, Thurman RE, Kaul R, Myers RM, Stamatoyannopoulos JA. Widespread plasticity in CTCF occupancy linked to DNA methylation. Genome Res 2012;22:1680-8

82 Li G, Fullwood MJ, Xu H, Mulawadi FH, Velkov S, Vega V, Ariyaratne PN, Mohamed YB, Ooi HS, Tennakoon C, Wei CL, Ruan Y, Sung WK. ChIA-PET tool for comprehensive chromatin interaction analysis with paired-end tag sequencing. Genome Biol 2010;11:R22

83 Santagati F, Abe K, Schmidt V, Schmitt-John T, Suzuki M, Yamamura K, Imai K. Identification of Cis-regulatory elements in the mouse Pax9/Nkx2-9 genomic region: implication for evolutionary conserved synteny. Genetics 2003;165:235-42.

84 Wang YL, Faiola F, Xu M, Pan S, Martinez E. Human ATAC Is a GCN5/ PCAF-containing acetylase complex with a novel NC2-like histone fold module that interacts with the TATA-binding protein. J Biol Chem 2008;283:33808-15.

85 Franceschini A, Szklarczyk D, Frankild S, Kuhn M, Simonovic M, Roth A, Lin J, Minguez $P$, Bork P, von Mering C, Jensen LJ. STRING v9.1: protein-protein interaction networks, with increased coverage and integration. Nucleic Acids Res 2013:41(Database issue):D808-15.

86 Hamdan H, Liu H, Li C, Jones C, Lee M, deLemos R, Minoo P. Structure of the human Nkx2.1 gene. Biochim Biophys Acta 1998;1396:336-48.

87 Ikeda K, Clark JC, Shaw-White JR, Stahlman MT, Boutell CJ, Whitsett JA. Gene structure and expression of human thyroid transcription factor- 1 in respiratory epithelial cells. J Biol Chem 1995;270:8108-14. 


\section{MG Comprehensive genotyping and clinical characterisation reveal 27 novel NKX2-1 mutations and expand the phenotypic spectrum}

Anne Thorwarth, Sarah Schnittert-Hübener, Pamela Schrumpf, Ines Müller, Sabine Jyrch, Christof Dame, Heike Biebermann, Gunnar Kleinau, Juri Katchanov, Markus Schuelke, Grit Ebert, Anne Steininger, Carsten Bönnemann, Knut Brockmann, Hans-Jürgen Christen, Patricia Crock, Francis deZegher, Matthias Griese, Jacqueline Hewitt, Sten Ivarsson, Christoph Hübner, Klaus Kapelari, Barbara Plecko, Dietz Rating, Iva Stoeva, Hans-Hilger Ropers, Annette Grüters, Reinhard Ullmann and Heiko Krude

J Med Genet 2014 51: 375-387 originally published online April 8, 2014 doi: 10.1136/jmedgenet-2013-102248

Updated information and services can be found at:

http://jmg.bmj.com/content/51/6/375

These include:

\section{Supplementary} Material

References

Email alerting service
Supplementary material can be found at:

http://jmg.bmj.com/content/suppl/2014/04/08/jmedgenet-2013-102248 .DC1

This article cites 85 articles, 22 of which you can access for free at: http://jmg.bmj.com/content/51/6/375\#BIBL

Receive free email alerts when new articles cite this article. Sign up in the box at the top right corner of the online article.

$\begin{array}{cc}\text { Topic } & \text { Articles on similar topics can be found } \\ \text { Collections } & \text { Asthma (21) } \\ & \text { Immunology (including allergy) (604) } \\ & \text { Molecular genetics (1254) }\end{array}$

Notes

To request permissions go to:

http://group.bmj.com/group/rights-licensing/permissions

To order reprints go to:

http://journals.bmj.com/cgi/reprintform

To subscribe to BMJ go to:

http://group.bmj.com/subscribe/ 